\title{
ENTERPRISE LIABILITY AND THE ACTUARIAL PROCESS-THE INSIGNIFICANCE OF FORESIGHT
}

\author{
G. ROBERT MORRIS, JR. $\dagger$
}

IN his famous article on "Frolic and Detour,"1 the late Dean Young B. Smith suggested that the problem of determining the "scope-of-employment" could be solved by determining the scope of "zones of risk" which entrepreneurs could foresee were incident to their businesses. Professor Ehrenzweig has recently taken much the same approach to the question of enterprise liability in conflict of laws. ${ }^{2} \mathrm{He}$ has suggested that choice-of-law problems in that context can be solved by rejecting the laws of those jurisdictions which were not "foreseeable and insurable" and against which, therefore, enterpreneurs could not have been expected to insure.

The zone-of-risk approach is based upon the "entrepreneur theory," a theory first publicized in this country by Dean Smith, ${ }^{3}$ and more fully developed by Douglas. ${ }^{4}$ Douglas pointed out that enterprise liability had managerial as well as financial functions. That is, not only could the entrepreneur insure and spread the risk, but he could also seek to minimize the loss or prevent it altogether. The zone-of-risk approach, however, is premised only upon the insurance and risk-spreading function of enterprise liability. It is the purpose of this article to investigate these insurance and risk spreading functions and to discover whether they provide a good prescriptive basis for legal theory.

Dean Smith's article announcing the entrepreneur theory was part of a continuing critique. Holmes had disparaged vicarious liability as contrary to common sense. ${ }^{5}$ Baty agreed. He found that nine justifications had been advanced for it. Eight of these, he argued, were false. Each rationale failed to cover a situation in which the law, nevertheless, imposed vicarious liability. "In hard fact," he concluded, "the real reason for employers' liability is the ninth: the damages are taken from a deep pocket." 6 Though this was the reason, it could not be justified. Baty could find no justice in respondeat superior.

†Professor of Law, Rutgers The State University School of Law, South Jersey Division.

1. Smith, Frolic and Detour, 23 CoLuM. L. Rev. 444, 716 (1923). Harper and James, in their recent treatise, have been influenced by this reasoning. 2 HARPER \& JAMIES, ToRTS 1375-76, 1385 (1956).

2. Ehrenzweig, Guest Statutes in the Conflicts of Lazes, 69 YALE L.J. 595 (1960); Ehrenzweig, Products Liability in the Conflict of Laws, 69 Y ALE L.J. 794 (1960); Ehrenzweig, Vicarious Liability in the Contfict of Laws, 69 YALE L.J. 978 (1960).

3. Smith, supra note 1.

4. Douglas, Vicarious Liability and Administration of Risk, 38 YALE L.J. 584, 720 (1929).

5. Holmes, Agency, 5 HaRv. L. Rev. 1, 14 (1882).

6. Baty, Vicarious Liabirity 154 (1916). 
Time has not been kind to Mr. Baty. Holmes' laurels are in other fields. Vicarious liability is as firmly entrenched in the law as if Baty and Holmes had been silent. And the justice of enterprise liability is now unquestioned, though the proper scope of such liability is still a matter of concern.

The entrepreneur theory is an important cornerstone of this modern view. As Dean Smith said, "[T] he justification for making the master liable for his servant's unauthorized torts is the desire to include in the costs of operation inevitable losses to third persons incident to carrying on an enterprise, and thus distribute the burden among those benefited by the enterprise ...."7 A different Smith put it more picturesquely : "business should pay its passage." Enterprise theorists observe that enterprise liability causes little business dislocation while, at the same time, it does important service by repairing injured limbs, replacing lost breadwinners, and making livable the invalid lives of industry's victims. The entrepreneur can avoid the shock effects of individual judgments by building a fund to pay them or by purchasing insurance. Since his competitors will have to do likewise no one suffers a competitive disadvantage. In this view the cost of insurance or funding is one of the regular costs of businesses and, as such, can be passed on to customers. In short, a victim's loss is shifted to one better able to bear it, and thence spread on to the customers who benefit from the productive activity. ${ }^{9}$ It is proper that they take the burden with the benefits. And, furthermore, since each customer's proportionate share is quite small, they can sustain the burden easily, whereas the original victim could not. ${ }^{10}$

It has been observed that liability in family automobile cases can be justified along similar lines. Heads of households must insure to protect family assets from judgment execution. Insurance here spreads the expense of automobile castualties among the class of car owners, those who benefit from automotive transportation. Families who own cars, then, take their share of the burden of automotive transportation along with its benefits. While a household is not usually considered an "enterprise," it is an economic unit providing service to its members, and Professor Ehrenzweig has considered the family automobile argument to be an aspect of the entrepreneur theory. ${ }^{11}$ Though some consider the term "entrepreneur" a misnomer," in this context it is a very perceptive analogy.

7. Smith, supra note 1 , at 718 .

8. Talbot Smith, Scope of the Business: The Borrozved Servant Problem, $38 \mathrm{MicH}$. L. REv. 1222, 1223 (1940).

9. Smith, supra note 1 , at $460-61$; see 1 LARson, WORKMEN's COMPENSATION LAW 2 (1952) ; 2 HARPER \& JAMres, TORTS 1364 n.12 (1956).

10. James, Accident Liability Reconsidered: The Impact of Liability Insurance, 57 YALE L.J. 549, 550 (1948).

11. Ehrenzweig, "Full Aid" Insurance for the Traffic Victim, 43 CALIF. L. Rev. 1, 4-5 (1955).

12. Prosser, Palsgraf Revisited, 52 MiCH. L. REv. 1, 31 (1953). 
Clearly, we must accept the functional observations upon which the entrepreneur theory rests. Shock losses are spread by way of insurance and through the channels of commerce, resulting in a net social gain. There are, of course, exceptions. Enterprise liability will not be beneficial in every case. A teenager may negligently collide the family car with a parked Standard Oil truck, in which case a judgment in favor of Standard Oil will shift a loss from one quite able to spread it. But since the family has liability insurance the process is not a complete evil. The loss will still be spread, and that is the main thing. The fact that the monetary outlay is almost twice the actual loss, because it includes the cost of the insurance company's operations, ${ }^{13}$ is an evil; but that increment is itself spread so thinly over the class of insured car owners that it is not a great evil.

One evil, however, may be greater. The shock loss of a large judgment cannot always be spread. It may, rather, destroy the financial integrity of a business or household enterprise. If the enterprise is uninsured and has no cash reserve, a judgment may ruin the business or may leave a family with only its exempt assets. The same result, of course, is possible if a judgment exceeds the maximum of the insurance policy or the reserve. Can the entrepreneur theory justify the harsh results in such cases? The answer given is that the entrepreneur should have adequately funded or insured. The entrepreneur must make provision for the costs of his enterprise or suffer financial failure. The law makes the risk of enterprise liability a cost of the enterprise. The entrepreneur who does not make provision for this cost should fail, just as one who does not provide for his labor cost or for interest on his borrowed capital will be put out of business. As Professor Ehrenzweig puts it, the law should not concern itself with the uninsured entrepreneur, but should decree liability in areas where "the defendant could reasonably be expected to carry such insurance. Not insurance, itself, obligates, but 'Assurabilité Oblige." "14

It is from this point that the zone-of-risk analysis proceeds. If the law requires an entrepreneur to insure the risks of his enterprise at his peril, then the law must take care to limit liability to those risks against which the entrepreneur can reasonably be expected to insure. But the entrepreneur can only be expected to insure those risks which he can foresee are incident to his enterprise. Therefore, enterprise liability should be limited to that zone of risk which the entrepreneur can anticipate. Fairness dictates that losses occurring beyond the boundaries of that zone should not be attributed to the entrepreneur.

Thus, after adopting the entrepreneur theory, Dean Smith observed:

[I]t does not follow that he [the entrepreneur] should be made responsible for any and every tortious act which his servant may commit. To make the entrepreneur responsible for acts of his employees in no way connected with the enterprise would be undesirable because it would re-

13. See text at pp. 565-66 infra.

14. Ehrenzweig, Assurance Obligé-A Comparative Study, 15 LAw \& Contenr. Prob. 445, 451 (1950). 
sult in including in the cost of production an item which economically does not belong there. ${ }^{15}$

Of course, here he envisaged an easy case, one not often litigated. The cases he was primarily concerned with were those in which the acts of the employees were somewhat connected with the enterprise. Typical of these are the truck accident cases, in which the driver had used his employer's vehicle for a personal errand. "The writer," said Dean Smith, "would confine the master's liability to deviations of the servant which, in view of what the servant was employed to do, were probable."16 This led Dean Smith to the zone of risk.

[A]n enterprise involving the employment of chauffeurs to drive trucks between particular points in New York City, does create a risk of injury to persons outside the limits of the direct, or authorized route. This risk results from the fact that chauffeurs frequently do make deviations from the authorized route. On the other hand, it isn't probable that a chauffeur who is told to drive from Times Square to Wall Street, will drive six or seven miles in the opposite direction. Consequently, it could hardly be said that an enterprise involving the employment of chauffeurs to drive trucks around the lower part of New York thereby created a risk of injury to people in the Bronx. ... [I] $n$ every case, there is a zone within which there may fairly be said to exist a risk of injury to others in view of what the servant was employed to do. ... [I]njuries occurring within the zone should be borne by the enterprise which caused the risk where it appears that the affairs of the enterprise were a contributing cause of the chauffeur's act in driving the car. ${ }^{17}$

Professor Ehrenzweig, in three articles all subtitled "Toward a Theory of Enterprise Liability Under 'Foreseeable and Insurable Laws,' "18 has recently used the same line of reasoning in connection with the choice-of-law problem in conflicts of laws. Though the scope of enterprise liability is roughly the same in all American jurisdictions, Professor Ehrenzweig has found three differences with which to illustrate his thesis: guest statutes, automobile owners' liability statutes, and laws imposing strict liability upon the sellers of defective food. He dissents strongly from the Restatement view that the law

15. Smith, supra note 1 , at 461 .

16. Id. at $724-25$.

17. Id. at 728 .

18. These articles, cited note 2 supra, are part of a series of articles by Professor Ehrenzweig which have appeared in connection with the completion of his book on conflicts, the first part of which has already been published. EnRENzwEIG, Conflict of LAws (1959). He has set out his basic approach to the choice-of-law problem in Ehrenzweig, The Lex Fori-Basic Rule in the Conflict of Lazes, 58 Mrcer. L. Rev. 637 (1960). His thesis is that the central problem of the law of conflicts is the ascertainment of a convenient forum. Once it is assured that cases will be heard only in convenient fora, courts can then be expected to apply the lex fori in most cases. "[C]onflicts rules . . would . . . come into play primarily in determining whether the defendant would be unfairly dealt with under the law of the forum ...." Id. at 645. Apparently, these three articles are intended to illustrate situations in which the lex fori should be displaced because "the defendant would be unfairly dealt with under the law of the forum." 
of the place of the injury governs. ${ }^{19}$ This may lead to liability not contemplated by the entrepreneur. If the owner of a car garaged in a guest statute state should have an accident in a nonguest statute state, the Restatement would have the common law of the nonguest statute state govern the suit by the guest against the owner, whether the case was brought in a guest statute state forum or not. Professor Ehrenzweig retorts: "It seems unreasonable to compel the host ... to buy insurance against a liability that he might incur under the law of a state possibly to be reached on a yet unplanned out-of-state trip." ${ }^{20} \mathrm{He}$ would allow the host to plea the guest statute in bar of liability. Under this rule,

the host will or could arrange his [insurance] protection with a view to [the guest statute of his own state] without fear of being subjected to a broader liability in a common-law state. His insurer will or could calculate his premium accordingly. And the prospective guest, aware of his limited protection, will or could be expected to purchase his own accident insurance. ${ }^{21}$

On the other hand, the driver of a car garaged in a nonguest statute state, who injured his guest in a guest statute state, could not plea the statute in bar of liability. His insurance premium was calculated to cover the risk of guest claims.

The owner's liability statutes which concern Professor Ehrenzweig provide that the owner-bailor of an automobile is liable for the negligence of his bailee even if the bailee is not a servant of the bailor, provided the car is being used with the bailor's permission. Connecticut, for instance, has such a law. ${ }^{2}$ Massachusetts does not. Again Professor Ehrenzweig would condition liability upon the law against which the owner had insured.

'Insurable laws' include at least the law of the defendant's domicile (or, in the automobile cases, the state where his car is permanently kept), the law of the place of the accident, and probably the law of the plaintiff's residence in this or a contiguous country. Among these laws, then, ... the plaintiff should be able to choose by choosing his forum [which should apply the lex fori]. But limits on the application of the lex fori are neces-

19. Restatement, Conflict of Laws $\$ 384$ (1934). This section invokes the law of the "place of wrong." This has been interpreted to mean the place of the injury, rather than the place of the substandard conduct. 2 BEALE, CoNFLICT of LAws $\S 377.2$, at 1287 (1935).

20. Ehrenzweig, Products Liability in The Conflicts of Laws, 69 Yale L.J. 794, 801 (1960).

21. Ehrenzweig, Guest Statutes in the Conflict of Laws, 69 YALE L.J. 595, 603-04 (1960).

22. This statute only applies to car rental agencies. ConN. GEN. STAT. REv. § 14-154 (1958). Similar statutes have been enacted in other states. Some states, however, have owners' liability statutes which cover all owners. CAL. VentcLe Code $\$ 17150$; Del. Code ANn. tit. 21, $\$ 6106$ (Supp. 1958) ; D.C. Code ANN. § 40-403 (1951); IdAHo Code ANN. $\$ 49-1404$ (1948) ; Mich. Comp. Laws $\$ 257.401$ (Supp. 1956); Mrnw. Stat. Ann. \$ 170.54 (1960); N.Y. Vehicle \& TRaffic LaW § 388. 
sary to exclude undesirable forum shopping. A Massachusetts plaintiff injured in his own state by a car rented in a state equally lacking an owners' liability law, should not be able to avail himself of the owners' liability law of Connecticut by bringing suit in that state after acquiring a mere transient jurisdiction over the defendant. ... [T] he defendant must be permitted to prove that Connecticut law was not one whose impact on its operations could reasonably have been foreseen and insured against-i.e., that its application to this particular case would be purely fortuitous. ${ }^{23}$

In contrast, Professor Ehrenzweig considers the case of a Connecticut resident, victim of an accident in Massachusetts caused by a car rented from a Massachusetts defendant. If suit were brought in Connecticut, Professor Ehrenzweig would permit the case to be decided according to Connecticut law; the Connecticut owner's liability statute would apply. Furthermore, the plaintiff should not be deprived of this choice of invoking Connecticut law "by being unable to obtain jurisdiction over the defendant in Connecticut [;] and [he] must, in a Massachusetts court, be permitted to rely on Connecticut law as one reasonably foreseeable and insurable by the defendant."24

To illustrate his point concerning products liability, Professor Ehrenzweig chooses Ohio, which, in common with at least twenty-one other jurisdictions, imposes strict liability upon vendors of defective food. ${ }^{25}$ He would impose strict liability upon all Ohio producers, even if the plaintiff was domiciled in one of the fourteen or more jurisdictions which adhere to the requirement that negligence be shown, and regardless of whether he had purchased and consumed the food in his home state. An Ohio producer, even if he markets interstate, can certainly foresee and insure against the impact of Ohio law. Also, a non-Ohio producer who markets in Ohio would be subject to the Ohio rule in a suit by one who purchased the food in Ohio, even if the plaintiff had to bring the suit in another state to obtain jurisdiction over the defendant. One who markets in Ohio knowingly assumes the added burden of Ohio law; he can foresee the risk and insure against it. However, a non-Ohio producer who does not market in Ohio and has no reason to anticipate that his product will be consumed there would not be subject to Ohio law. A traveler, then, who purchased the product of such a producer in New York, but consumed it and became ill in Ohio, could not claim the benefit of Ohio law, for Ohio law was not "foreseeable and insurable" by the producer. ${ }^{28}$

In short, then, Professor Ehrenzweig, by following the line of argument originally advanced by Dean Smith, has adopted a zone-of-foreseeable-laws concept which parallels Dean Smith's zone-of-risk analysis of the scope of

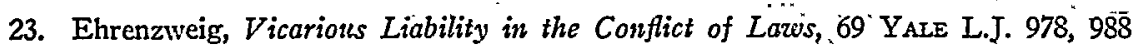
(1960).

24. Ibid.

25. The jurisdictions are counted and classified in Prosser, The Assault Upon the Citadel (Strict Liability to the Constimer), 69 Y ALE L.J. 1099, 1107-10 (1960).

26. Ehrenzweig, Products Liability in the Conflict of Lawe, 69 YaLe L.J. 794 (1960). 
employment. Both of these zones are defined by the extent of insurance coverage, or in the case of self-insurers the extent of foreseeable risk, for which entrepreneurs can be expected to provide.

The Smith-Ehrenzweig method for defining the extent of entrepreneur responsibility does not, in my opinion, stand up under analysis. It suffers from a number of related difficulties. First, it is based upon a mistaken concept of risk. Second, it fails to take into account certain insurance practices dictated by the nature of risk. Finally, it is tautological.

\section{The Cost of Enterprise Liability}

The zone-of-risk approach confuses the concept of risk in general with the concept of particular risks. A particular risk is important to one who wants to avoid a specific loss. But the entrepreneur is not concerned with a specific loss when he buys insurance or funds a reserve against enterprise liability. He wants to know the aggregate cost of those losses that he fails to avoid and for which he will be held liable. He is interested in the quantum of risk expressed in dollars and cents. He wants to know the cost, so that he can provide for it in an orderly manner.

\section{The Actuarial Process}

For this information, he must turn to an actuary. ${ }^{27}$ The actuary attempts to estimate the total cost of risks arising from the business, but for this he must make a number of assumptions. He first assumes that the immediate future will be much like the recent past. Last year's plaintiff will not be injured again next year, but someone much like him may well be. This assumption is valid only for large aggregates. In a very large enterprise the total number of claims will not vary much from year to year. It may be possible, then, to predict the cost of paid claims for next year from the cost of those made last year. The actuary might predict with reasonable accuracy the amount of enterprise liability for next year for an unchanged enterprise, if the enterprise were large enough. For smaller enterprises he will have to lump together the experience of a number of past years. His prediction in this case will not be valid for the coming year alone, for the same factors which make the law of averages not applicable to the most recent year alone also make it inappli-

27. I make no claim to expertise as an actuary. The following discussion of the actuarial process is largely based upon three works: Kulp, CAsualty Insurance 458532 (3d ed. 1956) ; Kulp, The Rate-Making Process in Property and Casualty Insurance -Goals, Technics, and Limits, 15 LAW \& ConTEArP. ProB. 493 (1950); Stern, Current Rate Making Procedures for Liability Insurance, in 53 Proceedings of the Casuaity Actuarial Society 112 (1956). I am further indebted to the actuaries of the National Bureau of Casualty Underwriters who have been most kind in answering my many questions about the practice of their art and have made available their recent studies of products liability rates and Delaware automobile liability rates. The views here presented are solely my own and are not necessarily those of the Bureau or any of its actuaries. 
cable to the single coming year. But the past three years, perhaps, can be used to predict the loss for the coming three years, and it is not unreasonable to say that the value of the risk for each of the three future years is really one third of the total three-year-risk. ${ }^{28} \mathrm{~A}$ surplus in one of those years is very likely to be offset by fewer claims in others. A business with sufficient reserves, or that business' insurer, can weather a storm of excess claims in some years, and in the long run maintain the integrity of its reserves, if one third of the probable three-year loss is set aside annually. A difficulty in prediction, however, arises from the fact that things will not be the same during the coming three years as they were during the past three. Inflation may increase the size of claims. A change in claim consciousness may change the frequency of claims. If the past years indicate a trend, an assumption must be made that the trend will continue, to some extent, into the coming period. ${ }^{29}$ Since all the actuary is attempting to calculate is one third the probable three-year total, so that a proper amount will be set aside during the coming year, this trend analysis can be relied upon. A year hence, an analysis can be made to discover whether the trend is continuing or not, and adjustments can be made in the amount to be set aside for the next, overlapping, three-year period.

Of course, this description is unreal in a number of particulars. First, even if we are going to calculate the amount of risk on the basis of one enterprise alone, that risk will not have remained constant during the past three years and cannot be expected to remain constant even during the next one or two years. For one thing, the size of the business will probably change, bringing with it a change in the amount of risk. Hence the actuary must derive a figure for each type of risky activity according to the volume of that activity. That is, he cannot figure merely the total amount of claims, but must calculate the amount of claims per unit of "exposure." Industrial accident claims vary with the size of the work force, automobile accident claims with the mileage covered, products liability with the quantity of sales, and so on. Also, within each of these categories the risk varies with the kind of activity. For instance, products liability risks vary with the kind of product sold: bottled beer is riskier than canned beer, as the risk of explosion and the problem of cleaning

28. In practice, one, two, three, or even five years' experience may be used. At one time, five years was commonly used, but there is a chance that the added accuracy which these additional years might supply will be counterbalanced by changed conditions. Obviously, the most recent data is more indicative of the immediate future than is data assembled a number of years ago.

It should be added that final data concerning recent years is not available. Last year's automobile accidents have already occurred, but the total amount of damage is, as yet, unknown. The final total of losses attributable to recent experience is projected, therefore, by estimating a "loss development factor": the ratio of the final total for a given year to that reported as of the end of that year, or as of twelve or twenty-four (or any other number) months after the end of that year. This factor is derived by comparing the final reports for prior years with the earlier reports for those same years. Stern, supra note 27 , at $119-22$.

29. See Stern, supra note 27, at 123. 
the containers are different; truck risks differ from car risks; miners are more likely to be killed than clerks. Thus, the actuary must first subdivide enterprise activity in general into various kinds of claims: workmen's compensation, products liability, automobile liability, etc. Then each of these must be further classified according to specific activity: brewer, five-and-ten, etc. And then, for each class, the actuary must find an appropriate "unit of exposure" -one which not only varies with the amount of risky activity, but which is also easily discovered from the books of the business. For example, while manhours might be the best unit for workmen's compensation, it would be difficult to abstract from the books. Therefore, dollars of payroll is used instead. Again, mileage might be best for automobiles and trucks, and in fact it is sometimes used. But the more common measure is simply the number of vehicles of each class, a rougher measure of automotive activity, but one more easily determined. For products liability, the unit of exposure is usually $\$ 1000$ gross receipts or sales. Where only one standardized product is involved, the unit can be stated in terms of the articles sold. In department stores, the unit is $\$ 1000$ of sales, but the unit for sugar refiners is 10,000 pounds of sugar, for tire manufacturers, 1000 tires. Sometimes compromises must be made. A brewery's risk of poisoning its customers probably varies with the number of gallons it sells, but this would be a poor measure for bottled beer, where the explosion risk varies with the number of bottles. Hence the unit for bottled beer is 10,000 bottles, but for beer in kegs it is 10,000 gallons.

By analyzing claims in relation to units of exposure, the actuary can ignore the fact that the size of the enterprise under study has changed during the years under study. Furthermore, his predictions will be useful to an entrepreneur who expects the size of his business to change during the next year. A brewer will know the cost of risk per truck, per dollar of payroll, and per bottle of beer.

Of course, the actuarial method described above would only work for a very large enterprise. When the various classes of risk are so finely subdivided, the amount of a particular enterprise's experience in each class can become so small that the law of averages can no longer be applied to it. One robin does not make a summer, and five paid claims do not indicate much about the level of risk. In the language of actuaries, it is no longer "credible."

One technique, however, can be used to increase the "credibility" of the data. While large claims are relatively infrequent, they greatly affect a simple ratio of losses to exposure when they do occur. If, for example, claims average around $\$ 1000$ each, a business which had to pay one hundred claims ought to show losses of around $\$ 100,000$. But if one of those claims results in a verdict of $\$ 100,000$, the total losses will be almost doubled. The frequency of large claims, however, can be considered to be the result of pure chance. Therefore, in making his initial computation, the actuary reduces the size of large claims to a relatively low figure, thus reducing the effect of such claims upon his calculations. From this initial figure and on the basis of the anticipated frequency of large claims, he can then project the actual amount of the risk. If by chance 
the particular experience being studied does not contain any large claims, he is able in this manner to calculate what the entrepreneur's share of the largeclaim risk is-the amount he should nevertheless be setting aside to pay the big claim which is probably going to crop up eventually. On the other hand, if the particular experience is by chance overloaded with large claims, this does not affect the actuary's calculations.

For instance, in calculating automobile liability and product liability rates the actuary considers only the "basic limits" experience. He omits from his calculations all "excess limits" claims by ignoring that part of any claim which exceeds $\$ 5000$. He is then able to evaluate the amount of "basic limits" risk. From prior experience, involving a much greater amount of data, he knows the ratio of basic limits risk to total risk. He can, therefore, project the total risk from the basic limits risk. ${ }^{30}$ This technique relies primarily upon that part of the given experience which is least subject to chance, that part which includes fewer "long shots" and is hence more credible than the total experience. But this approach can be followed only by projecting the basic limits figure thus derived according to a factor discovered from a study of a wider group of experience. At this stage the actuary has started to bring in the experience of other entrepreneurs. ${ }^{31}$

In general, however, the actuary must bring in the experience of others at the very beginning. Even in using the above technique, which limits his consideration to the least chancy part of the experience under study, the actuary must have a considerable amount of data. In the automobile liability field, for example, it is considered necessary to have experience involving at least 1084 losses before the experience can be judged completely credible. A lesser amount of experience is not totally useless, but is weighed according to a slid-

30. This is an oversimplification because the actuary for an insurance company never attempts to calculate the total risk. He always limits the amount per claim. In other words, he does not project from basic limits to total risk; he projects from basic limits $(\$ 5000)$ to some higher figure, say $\$ 10,000, \$ 100,000$ or $\$ 300,000$. For higher figures, of course, the experience is less credible than for lower figures. Claims in the range from $\$ 5,000$ to $\$ 10,000$ may be frequent enough so the ratio of that risk to the basic limits risk can be easily determined, but claims above $\$ 100,000$ are not frequent enough to permit a reliable calculation. The upper reaches of excess limits risk, therefore, are determined by projecting the lower figure according to laws of chance.

31. In calculating workmen's compensation rates, a slightly different technique is used. Claims are divided into three categories: serious, nonserious, and medical, and pure premiums are calculated for each. Serious claims are less frequent and less likely, therefore, to be credible. Nonserious and medical claims, being more frequent, are more credible. Each part of the experience is evaluated according to its credibility. See note 32 infra and accompanying text. This means that the actuary's final estimate of the nonserious and the medical part of the risk is likely to be based upon recent experience, but his estimate of the serious part of the risk will be merely an adjustment of estimates of prior years in the direction indicated by the partially credible serious claims experience. See KuLP, CAsUaLty INsurance 472-73 (3d ed. 1956) ; Kulp, The Rate-Making Process in Property and Castalty Instrance-Goals, Technics, and Limits, 15 LAW \& C̣oNTEMP, Prọ. 493, 508 (1950). 
ing scale. ${ }^{32}$ An experience with one quarter of the losses has one half the credibility. Thus, if there are only 271 losses the experience is said to have 50 per cent credibility, which means that the result will only be half-relied upon. The practical meaning of this is that if an actuary had to rely upon such experience to change an existing rate of insurance he would make only half the adjustment indicated. Similarly, if the experience had only forty losses per year it would be considered 10 per cent credible, and he would make only one tenth of the change indicated. Meager experience, then, can be used to adjust a rate, though the actuary approaches the true rate somewhat the way Achilles caught the Tortoise. His progress is not as unrelenting as Achilles', for the small amounts of experience have too many chaotic factors. Experience involving 271 claims a year would not indicate the true rate each year, so unlike Achilles the actuary would not advance exactly half the true distance each time.

Most entrepreneurs do not have 1084 automobile liability claims per year. Very few, probably, have even forty. In order to amass data with sufficient credibility to estimate the amount of risk involved the actuary must, therefore, combine the experience of a number of entrepreneurs. He does this by establishing territories within which, he assumes, entrepreneurs are roughly the same. In theory, the boundaries of these territories should be drawn along functional lines, to separate urban from rural conditions, mountains from plains, etc. In practice, many territories are bounded by city limits and county lines. Large cities are often surrounded by a "suburban" territory which was drawn along functional lines, but the recent growth of suburbs has made many territories obsolete. It is difficult for the actuaries to revise these territories because their data is categorized according to the present pattern of territories. There is, therefore, an unavoidable lag between changing land-use patterns and the revision of rate territories.

32. This scale is as follows:

$\begin{array}{cc}\text { Number of Claims. } & \text { Credibility. } \\ 0-10 & 0 \% \\ 11-42 & 10 \% \\ 43-97 & 20 \% \\ 98-172 & 30 \% \\ 173-270 & 40 \% \\ 271-389 & 50 \% \\ 390-530 & 60 \% \\ 531-693 & 70 \% \\ 694-877 & 80 \% \\ 878-1083 & 90 \% \\ 1084 \text { and over } & 100 \%\end{array}$

KuLP, op. cit. supra at 478.

Different lines of insurance present different problems and have different standards of credibility. Thus, for products liability, a similar table has been worked out, but 683 claims have been considered $100 \%$ credible. In workmen's compensation, credibility is evaluated in terms of the total amount paid, rather than the number of claims. Since the amount paid is somewhat related to the number of claims, credibility is indirectly a function of the number of claims. KuLP, op. cit. supra at 473. 
It is important to keep in mind that these territories are aggregates of assureds, not aggregates of claimants or accidents. Thus, a claim against an entrepreneur is allocated to his territory even if the accident giving rise to the claim was outside the territory, the claimant resided outside the territory, or suit was brought in a remote jurisdiction.

With such territories the actuary attempts to collect sufficient experience from a group of entrepreneurs to be able to estimate the amount attributable to each. He estimates the entire group's risk, and then assumes that each member of the group is responsible for a share of this risk in proportion to that member's share of the units of exposure in the group. This is valid only if the group is entirely homogeneous. The actuary, therefore, would like to subdivide territories and callings in order to make the group as small as possible. But as he does so the amount of experience decreases toward the point of no credibility. He must strike a careful balance between homogeneity and credibility. Furthermore, a multiplication of classifications complicates the process of gathering and evaluating the experience.

[D] ue consideration ... has to be given to the value of the information to be obtained in relation to the expenditure in man hours and equipment it takes to produce the data, and the ability of the companies and the [rate making] Bureau to produce and process the reported data within reasonable time limits. ${ }^{33}$

Finally, territories must be reasonably easy to identify, so that agents can calculate the rates on policies written. The actuary must, therefore, be content in most cases with this grouping procedure, using quite large groups. The true risk of a small entrepreneur cannot be calculated.

What is the figure, then, which the actuary derives? First, it is usually based on a number of years' experience, so it is simply a fraction of the estimated risk for a number of years. Second, it is usually based on the experience of a large group of entrepreneurs, so the rate per unit of exposure is a fraction of the estimated total risk of those entrepreneurs. Third, it is based upon the basic limits risk of those entrepreneurs, projected according to the ratio of basic limits risk to the excess limits risk of a much larger group of entrepreneurs. The actuary, then, rather than calculating an entrepreneur's risk, attributes to him a fraction of a territorial group's risk, which is not even that group's risk, but rather the product of a part of the group's basic limits risk for the past few years times an excess limits risk factor which has been derived from a still larger amount of experience.

These actuarial calculations yield what actuaries call the "pure premium" per unit of exposure: i.e., the amount of losses which an insurer will attribute to each such unit and which must be covered by the premiums he receives. Of course, the gross premium must be larger than the total of "pure premiums." The insurer is selling indemnification. It is hoped that the sum of pure premiums will equal the sum of payments in indemnification; but insurance com-

33. Stern, supra note 27 , at $115-16$. 
panies cannot sell at cost. There must be a mark-up, or in actuarial terms an "expense loading." This is accomplished by deciding what percentage of an insurance company's gross income must go for profit and for such expenses as agents' commissions, actuarial service, management, etc. This figure, expressed as a percentage, is termed the "expense ratio." Its compliment is the "loss ratio." Together, they add up to 100 per cent. If the "loss ratio" is 55 per cent, then the rate must be set so that the "pure premium" is 55 per cent of it. That is, the rate is the quotient of the "pure premium" divided by the "loss ratio." This is the "manual rate," the rate which the small insured pays when he purchases insurance.

Large enterprises, on the other hand, do not pay the manual rate. They have meaningful experience of their own, and hence it is possible to assign them individual rates. If their experience is better than the norm, they receive some benefit through lower rates; but if their experience is worse, they will feel some of the additional burden because their rates will be set above the manual rates. The rates of most individually rated firms are only slightly different from the manual rates, however, because their experience is not sufficiently large to be completely credible. Rather, they are charged a basic limits rate which is a mean between the manual rate and the rate indicated by their own experience. The mean point selected varies directly with the credibility of their individual experience, so that the smaller the credibility, the closer the rate charged approaches the manual rate and differs from the rate indicated by the individual enterprise's experience. Since the credibility of most firm's experience is relatively low, most individual rates do not differ greatly from the manual rate. ${ }^{34}$

34. The National Bureau of Casualty Underwriters' automobile liability plan for New York State, for instance, is only applicable to enterprises with at least five vehicles (or three buses) and which would, except for the plan, pay an annual premium of $\$ 1,000$ or more. Except for very large enterprises, those whose premium at manual rates would exceed $\$ 29,215$ annually, the plan concerns only the basic limits premium. Since excess limits premiums are a standard multiple of basic limits rates, however, any basic limits adjustment changes the excess limits premium also. The plan, however, is not based upon all basic limits experience, but only upon the even more credible experience below a ceiling which varies with the size of the enterprise, from $\$ 1,850$, for the smallest which qualifies, on up. The credibility of the particular enterprise's experience can be deduced from the following table of examples:

$\begin{array}{cc}\text { Total premium at Manual Rate. } & \text { Credibility. } \\ \$ 1,000 & 9 \% \\ 1,696 & 15 \% \\ 2,423 & 20 \% \\ 4,185 & 30 \% \\ 6,529 & 40 \% \\ 9,802 & 50 \% \\ 29,216 & 75 \% \\ 85,239 & 90 \% \\ 275,000 \text { or more } & 100 \%\end{array}$

The rate charged is a weighted average between the rate indicated by the experience and the manual rate. Thus, if a company's manual rate was $\$ 1696$, the credibility of its 
This description of the actuarial process is necessarily overgeneralized, and consequently it may be misleading. ${ }^{35}$ Before going further, therefore, it would be well to describe more specifically the methods used by the National Bureau of Casualty Underwriters in setting automobile liability and products liability rates. The Bureau and the Mutual Insurance Rating Bureau set the majority of rates in the nation. Their methods are very similar. ${ }^{36}$

\section{Auto Liability Rates}

Automobile liability insurance rates are made separately for three general groups of risks: private passenger cars, commercial vehicles, and garages. Passenger car rates are set by first determining the state-wide average basic limits premium. This premium will not be paid by any car owner, but it is the point of departure for the rate making process. The average premium is derived from the experience of one year. In smaller states, where one year's experience is correspondingly smaller, two years are used, with greater weight being given the most recent year. The indicated average pure premium deduced from this experience is then adjusted for trend. The past number of years have witnessed an increase in the size of claims. Nation-wide, the average bodily injury basic limits claim has increased from $\$ 663$ in 1955 to $\$ 753$ in 1959. The state's trend is projected, and the indicated average pure premium for basic limits is adjusted accordingly. ${ }^{37}$ Dividing this figure by the proposed loss ratio, the Bureau derives the state-wide average basic limits rate.

experience would be $15 \%$. If its own experience indicated a rate of $\$ 1000$, its final rate would be $.15 \times 1000$ plus $.85 \times 1696$ or $\$ 1592$. Simply stated, the entrepreneur would be awarded $15 \%$ of the difference between his indicated rate and the "manual rate." A large entrepreneur, one whose "basic limits" premium at manual rates was $\$ 9802$, could claim a credibility of $50 \%$ and thus receive half the benefit (or burden) of the difference between his indicated rate and the manual rate.

Experience rating plans are quite varied and are often complex. For a more complete description of them see KuLP, op. cit. supra note 32, at 486-532.

35. Id. at 481.

36. Some companies make their own rates, or set their rates a fraction below the Bureau rates because their selling cost, and hence their expense ratio, is less.

37. This trend analysis may be based in part upon the nationwide trend because the state's experience is likely to lack complete credibility. Credibility criteria for trend analysis must be higher than those used in other phases of rate making. Because trend is discovered by comparing the average claim in a recent year with the average claim in a previous one and then projecting into the future, slight errors in individual year's averages can cause a large error in the projection. If the errors in each average are in opposite directions (e.g., 1958's average is slightly low and 1959's is slightly high), the errors will be cumulative. Therefore, bodily injury trends require $\$ 7,500,000$ total basic limits claims a year for complete credibility. Property damage experience of $\$ 1,000,000$ a year is also fully credible. The trend for those states which fail to meet these standards is assumed to lie between the state's indicated trend and the nationwide trend, weight being given to the state's indicated trend in proportion to the credibility of its experience. 
Then, the average premium for each rating territory within the state is determined. This is done by comparing the territory's experience for three years with the state-wide experience for the same period in order to discover how much more or less risky the territory is than the state in general. This ratio, which is really the ratio of the state-wide average pure premium to the territory average pure premium, is also the ratio between the state-wide average rate and the territory average rate, since all rates have the same loss ratio. This ratio, then, times the indicated state-wide average premium, yields the average premium for the territory. Of course, many territories lack fully credible experience, even when three years' experience is combined. In such cases the indicated premium must be adjusted in the direction of the state-wide premium in proportion to the lack of credibility. ${ }^{38}$

One further adjustment is necessary. In most states there are nine classifications of private passenger car risks. Passenger cars used in business are in class 3 . Privately owned cars regularly driven by a male under 25 are in class $2 \mathrm{~A}$; but if the male under 25 also owns the car and is unmarried, the car is in class $2 \mathrm{C}$. Other individually owned cars are in class $1 \mathrm{~A}$; unless they are used to drive to work, in which case they are in $1 \mathrm{~B}$ or $1 \mathrm{C}$ depending upon whether the trip to work is less or more than ten miles. Finally, there are three special classifications for farmers, $1 \mathrm{AF}, 2 \mathrm{AF}$, and $2 \mathrm{CF}$, which correspond to classes $1 \mathrm{~A}, 2 \mathrm{~A}$, and $2 \mathrm{C}$.

The relationship between the rates for these different classes has been worked out on a percentage basis. That is, the riskiness of class $1 \mathrm{~A}$ has been compared to the riskiness of each other class on a substantially nation-wide basis. Some states have not approved the plan, so their experience has not been used. Furthermore, large cities have displayed a different pattern from small cities and rural areas, so their experience, nation-wide, has been computed separately. On the basis of this experience, it has been found that $1 \mathrm{AF}$ automobiles (farmers) have 70 per cent of the risk of $1 \mathrm{~A}$ automobiles. Class 3 risks are 150 per cent of $1 \mathrm{~A}$ risks. The large city $2 \mathrm{C}$ risk is 310 per cent of $1 \mathrm{~A}$, but in rural and small city territories, it is 360 per cent of $1 \mathrm{~A}$.

These factors, which are based upon experience from other states and other territories, are then used to set the rates for each class in each territory. This is done by first determining the $1 \mathrm{~A}$ rate. The present ratio of the $1 \mathrm{~A}$ rate to the average rate in the territory under the previous rates is calculated. Since

38. Actually, the proposed average rate for the territory is never derived as such, but it is implicit in the Bureau's calculations. The ratio of that rate to the state-wide rate is derived by comparing the loss ratio for the territory with the loss ratio for the state as a whole. Any lack of credibility in the territory's experience is compensated for by adjusting this ratio toward unity. This ratio times the proposed state-wide average premium gives the proposed average premium for the territory. These figures are not multiplied together, however, until after the differential between the territory's average premium and the class $1 \mathrm{~A}$ premium is also worked out, as described below. Then all three factors, the state-wide average premium, the ratio of the territory's experience to the state as a whole, and the class $1 \mathrm{~A}$ differential, are combined to yield the $1 \mathrm{~A}$ rate. 
the percentage differentials between classes remain unchanged this ratio will remain the same under the new rates. This ratio times the proposed average rate for the territory will yield the new class $1 \mathrm{~A}$ rate. The $1 \mathrm{~A}$ rate thus deduced is then rounded off to the nearest dollar. The rates for the other classes are then set by multiplying the established class rate differentials times the rounded-off $1 \mathrm{~A}$ rate; the rates for these other classes are then, in turn, rounded off to the nearest dollar. Usually the rounding off cancels out, there being as many upward as downward adjustments in each state's rates. However, the total revenue which the proposed rates will bring in is compared with the total revenue which a standard charge of the state-wide average manual rate would yield; if the figures differ by more than 1 per cent adjustments are made to reduce the difference.

The above calculation yields the basic limits rate for each territory and classification. Excess limits rates are not separately computed. Instead, they are set at a multiple of the basic limits rate. Generally, for passenger cars, insurance providing up to $\$ 300,000$ in coverage costs 160 per cent of the basic limits rate. A table of such ratios has been calculated upon substantially nation-wide experience, and it is used in all but four states. In these four (Florida, Illinois, Louisiana, and Oklahoma) which have exhibited higher excess limit losses, a separate table has been worked out.

The process for setting commercial vehicle rates is substantially the same. However, the state-wide average is based upon the two years' experience, each year having equal weight. The ratio of average territory rates to the average state rate is based upon five years' experience instead of three. There are eleven major classes, based upon the kind of business and the size of the vehicle. Finally, there is a different excess limits table, with a special table for Florida, Illinois, Louisiana, and Oklahoma. As one would expect, the excess limit differentials are higher for commercial vehicles than for passenger cars.

This method permits rates for very small classes which by themselves would have experience of very little credibility. Each rate is based upon recent, state-wide experience as the state rate level is determined from the experience of one or two recent years. But the final basic limits rate is determined by multiplying the state-wide average rate by two differentials: the territory's differential as indicated by three or five years' experience, and the classification differential based upon substantially nation-wide experience. Since the rate differential for class $1 \mathrm{AF}$ (farm automobiles not driven by a male under 25) is 70 per cent of the $1 \mathrm{~A}$ rate, the $1 \mathrm{AF}$ rate for the District of Columbia is as easily determined as the $1 \mathrm{AF}$ rate for the rural counties of Iowa.

\section{Products Liability Rates}

Products liability rates are worked out jointly by the National Bureau of Casualty Underwriters and the Mutual Insurance Rating Bureau. However, for about one quarter of the risks (measured according to the amount of basic 
limits claims) there are no uniform rates, because the hazard in some industries varies too much from enterprise to enterprise. For the remaining three quarters of insurance uniform rates have been established according to industries and, in some cases, kinds of product.

With some exceptions, products liability rates are not calculated on a stateby-state basis. Most rates are uniform throughout the country. There are two reasons for this. First, manufacturers are likely to market over a wide area so that the location of their plants is not a significant risk-changing factor. Second, though retailers market locally, the credibility of their experience on a state-by-state basis would be too low to set reliable rates. ${ }^{30}$ This latter factor is not true of New York State; special rates have been set there for bodily injury in 38 classifications. ${ }^{40}$ Ninety-eight classifications have nation-wide bodily injury rates, and all property damage rates are nation wide. Therefore, products liability rate making requires four separate calculations: one for the property damage rates, nation-wide; one for the 38 special New York State rates; one for these same 38 classifications for the balance of the nation; and one for the 98 nation-wide bodily injury rates.

New products liability rates were promulgated in May, 1960. The method of calculating these rates was different from that used for automobile liability rates. It was based entirely upon loss ratios. The Bureau attempted to set each rate so that its experienced loss ratio would be 54 per cent. The calculation of the 98 nation-wide bodily injury rates, which was typical of the four different calculations, began with an examination of the experienced loss ratio for all 98 classifications combined for the years 1955 and 1956, the most recent

39. Credibility criteria in the products liability field are lower than in automobile liability. Only 683 claims are necessary for complete credibility. Experience of 171 to 245 claims has $50 \%$ credibility. Property damage claims for all manually rated classes from companies reporting to either the National Bureau of Casualty Underwriters or the Mutual Insurance Rating Bureau (which combined their data in making the rates) included somewhat less than 5,000 claims a year. Bodily injury claims for those classes with nationwide rates were approximately 6,000 claims a year. No figures are available dividing the claims according to the location of the injury or the residence of the victim, since the bureaus attribute all claims to the location of the insured. However, there are clearly fewer claims than would be necessary for significant credibility in many of the fifty-two jurisdictions (the fifty states plus the District of Columbia and Puerto Rico). When individual classes are considered, the problem is even worse. Of the ninety-five classes with nationwide bodily injury rates, only fifteen had bodily injury experience with a credibility of over $50 \%$ when the experience of four years was lumped together. Fifty-three, on the other hand, had experience with less than $20 \%$ credibility. Some of these included an extensive amount of business. Sugar refining of over six billion pounds a year had only $10 \%$ credibility. That means there were between seven and twenty-six claims in a four year period. In the thirty-eight nation-except-New York classes, the picture was somewhat better. Eighteen had credibility over $50 \%$, and only 9 had a credibility of $20 \%$ or less for the four years.

40. In addition, there are a few other rates which are set for particular states: bodily injury for bakeries in Massachusetts, property damage for highway construction in New York, property damage for gasoline pump lessors in New York, and both property damage and bodily injury for pineapple canners in Hawaii. 
years for which experience was available. For those two years, the experienced loss ratio for the 98 classes combined was 51.2 per cent at the old manual rates. This meant that those rates, as a group, were too high and should be reduced 5.2 per cent. But a 5.2 per cent reduction of each of the 98 rates would not have been fair, since some of the rates were more out of line than others. Therefore, the Bureau endeavored first to establish a tentative schedule of rates which would be equally unfair to all classes. That is, it attempted to establish a tentative schedule of rates in which each rate had a loss ratio of 51.2 per cent. Then the tentative schedule of rates could be uniformly reduced by 5.2 per cent to bring the loss ratio for class up to the desired 54 per cent.

In calculating the tentative schedule, four years' experience was used. This greatly increased the credibility of each class's experience. It also, of course, involved the use of some older experience, experience too old to be reliable in setting the final rate. However, it could be assumed that this older experience would provide a reliable indication of the difference between each specific class and the norm for all classes, so that the rates' loss ratios could be equalized on the basis of this experience. The plan was to discover the actual loss ratio for each class for the four years; compare it with the mean loss ratio of all classes during those same four years; and then establish a tentative rate for each class which would make each loss ratio equal the mean loss ratio of all 98 classes. Thus the tentative schedule would be equally unfair to all classes as they would each have the same loss ratio.

The experienced loss ratios of many of the classes, however, could not be relied upon because these classes lacked credibility, even when the nation-wide experience from four years was taken together. The Bureals, then, had to hypothesize loss ratios for these classes. It did this by calculating a weighted average between the experienced loss ratio for each noncredible class and the mean loss ratio for all 98 classes, giving the experienced loss ratio a weight commensuate with its credibility. That is, the experience of a class with very little credibility was given very little weight; its actual loss ratio was assumed to be very close to the mean loss ratio. On the other hand, the experience of a class with 90 per cent credibility was given great weight; its actual loss ratio was assumed to be quite close to its experienced loss ratio. Of course classes with complete credibility were unadjusted, while those with zero credibility were assigned the mean loss ratio. The important thing to bear in mind is that these adjustments for credibility caused an adjustment of the loss ratios for noncredible classes towards the mean loss ratio of all classes.

Now, using these adjusted loss ratios, the Bureau attempted to equalize the unfairness of the rates. Classes with adjusted loss ratios of 120 per cent of the mean loss ratio were tentatively given an increase to 120 per cent of their old rate; classes with adjusted loss ratios of half the mean loss ratio had their rates tentatively cut in half, etc. The rates in the tentative schedule, therefore, had equal loss ratios (as adjusted for credibility) and could be considered equally unfair. 
But this schedule of tentative rates proved to be faulty. In the attempt to make exact calculations for each rate an error had been made concerning the whole. The tentative rates were not supposed to change the general rate level. The old rates were, as a whole, 5.2 per cent too high. The tentative rates were supposed to retain that error, but make each rate equally unfair-that is, each 5.2 per cent too high. If this had been achieved, the tentative rates would have yielded the same total premium for the 98 classes combined that the old rates had. However, the tentative schedule was too high. If it had been promulgated, the gross receipts from the 98 classes combined would have been increased by well over 3 per cent. This error was primarily due to the adjustments for credibility. The noncredible classes' experienced loss ratios had been adjusted toward the mean. It so happened that most noncredible classes had experienced loss ratios below the mean, so the adjustment increased more of them than it decreased. The noncredible classes, as a group, were therefore assumed to have higher actual loss ratios than they had actually experienced, so that their tentative rates were, in general, set too high. This error was apparent only when all the rates were considered together. The lack of credibility prevented any judgment concerning the propriety of most individual rates in the tentative schedule, so the error could not be corrected by adjusting particular rates.

To compensate for this error, all the rates in the tentative schedule were reduced by 3.6 per cent. This brought the rate level of the tentative schedule down to the actual rate level of the old rates. That is, if this reduced tentative schedule had been promulgated it would have yielded the same gross premium for the 98 classes combined as the old rates had. After the 3.6 per cent compensating reduction was made, the new rates were computed by further reducing each rate by 5.2 per cent, the reduction originally calculated to correct the fact that the old rate level was too high. ${ }^{41}$

The anomaly inherent in this method of rate-making can be best understood if we assume that one of the classes with completely credible experience should have been reduced 5.2 per cent. In other words, its loss ratio by chance equalled the loss ratio of all classes combined. If its rate were reduced 5.2

41. This description of the method used is somewhat simplified. Actually, the tentative schedule of rates was not developed by the Bureau, but it was implicit in the calculations, because the Bureau did develop a schedule of factors which, if multiplied by the old rates, would yield rates with equalized loss ratios. Furthermore, the above description is misleading in indicating that the Bureau explicitly made an across the board reduction of $3.6 \%$ to keep the tentative rates at the old rate level. This, too, was implicit in the Bureau's calculations, however, because the schedule of factors which the Bureau did develop had the $3.6 \%$ reduction built into it. This was done by calculating a new mean loss ratio for the table of loss ratios after they had been adjusted for credibility and developing the factors as ratios between this new mean average and the loss ratio. Since this new mean average was almost $4 \%$ higher than the actual mean for all classes, the factors included the $3.6 \%$ reduction mentioned in the text. These factors were then reduced by $5.2 \%$ and the new rates were derived by multiplying these reduced factors times the old rates. 
per cent, its loss ratio would be exactly the ratio desired. However, the above method of rate making would cause its rate to be reduced an additional 3.6 per cent. This is because its rate on the tentative schedule would be its old rate, unchanged by adjustments for credibility (since its experience was completely credible) or adjustments to the tentative schedule (because it already had the same loss ratio as all classes combined). But then, in common with all rates on the tentative schedule, its rate would be reduced first 3.6 per cent and then 5.2 per cent, so that its rate would be too low to the extent of 3.6 per cent. Furthermore, this would be true of the rates for all classes with completely credible experience. Each would have a rate 3.6 per cent lower than its own experience, taken by itself, would dictate.

It should be added that this 3.6 per cent anomaly in the computation of the 98 nation-wide bodily injury rates was the smallest in the four sets of calculations involved in the recent products liability rate revision. The comparable adjustment in the property damage rates was 4.4 per cent. For the special New York bodily injury rates it was 6.5 per cent; and in the calculation of the rates for those same classes for the balance of the nation it was 11.3 per cent. This means that the rates for classes with completely credible experiences were off by as much as 11.3 per cent. This, of course, was compensated by equal errors in the other direction in the rates for classes with less credible experience. The distribution of those errors, however, cannot be stated with certainty, since the noncredibility of those classes' experience does not permit any estimate of what the rates for those classes should have been.

This method of rate making is a modification of the "loss ratio method" of setting rates. In contrast with the "pure premium method," used in automobile liability rate making, the loss ratio method is less concerned with measuring the amount of risk in each classification than it is with being sure that the ratio of total losses to total premiums will equal the loss ratio built into the rates. Thus, insurers will neither lose money nor make excessive profits. ${ }^{42}$ While this method yields a rate for each class, including those with only slightly credible experience, each rate is somewhat dependent upon the experience in the other classes involved in the same calculation. This is clearly true for the noncredible classes, for their experience is adjusted to conform somewhat with the experience of all classes. Thus, the sugar refiner's rate is partially dependent upon the experience in other industries, including tire manufacturing, breakfast food making, and the packing of nonedible animal products. But furthermore, unless the noncredible classes' experience is balanced around the mean of all classes, credibility adjustments will put the entire calculation out of balance; and the method for regaining that balance affects all rates, credible or not. While attempts are made to set rates fair to each class of entrepreneurs involved, fairness often must take a back seat to adequacy of rates. The main emphasis is upon the general rate level, rather than upon specific rates.

42. See Kulp, The Rate-Making Process in Property and Casualty Insurance-Goals, Technics, and Limits, 15 LAW \& Contemr. ProB. 493, 500-01 (1950). 
In two respects, product liability rates and automobile liability rates are comparable. The rounding-off practice has about the same effect in each. The basic limits rates, which rarely exceed 60 cents, are rounded off to the nearest cent, except that those under 5 cents are rounded off to the nearest mill. Also, extended limits rates are calculated in the same way. In fact, the table generally used in products liability is the same as the table generally used in automobile liability insurance. Some classes, however, have exhibited greater "excess limits" losses than is usual, and for them there is another, higher table.

\section{The Erroneous Link Between Insurability and Entrepreneurs' FORESIGHT}

In general, then, the actuarial process produces a generalized measure of risk. The actuary deduces this figure from data concerning a large number of recent events, which he projects into the future. The risk allocated to a unit of exposure or to the usual enterprise is merely a fraction of that general risk. Furthermore, the actuary does not analyze all of the risk-causing factors. To be sure, some analysis of this kind is implicit in his division of lines of insurance into products liability, automobile liability, etc., and the further subdivision of those lines. Some further analysis of this kind is also implicit in the setting of rate territories to distinguish metropolitan risks from rural ones, etc., and in the division of automobile risks according to the uses of cars and the ages of the drivers, but this is a gross analysis. A very fine analysis is not attempted. Similarly, while foresight is an actuarial tool, it is used sparingly. The actuary's major premise is that the future will be much like the past, that it will have the same rough mixture of routine and peculiar events.

\section{The Actuarial Reality of the Zone of Risk}

Turning to the zone-of-risk theories, it can easily be seen that their concept of risk has little in common with the quantum of risk discovered by actuarial techniques.

Consider the guest statute problem. Professor Ehrenzweig states that "It seems unreasonable to compel the host [whose car is garaged in a guest statute state], as we do now, to buy insurance against a liability that he might incur under the law of a [nonguest statute] state possibility to be reached on a yet unplanned out-of-state trip." 43 But is it really unreasonable to require him to insure against this out-of-state risk? It should be remembered that his insurance premium was not calculated to cover his personal risk, but was rather his fraction of the aggregate premium necessary to cover the total risk posed by automobiles garaged in his rate territory. Whether that premium reflects guest claims depends upon the frequency of those claims.

Some car owners from that rate territory will undoubtedly drive their cars into nonguest statute states. They will have accidents in those states. Most of

43. Ehrenzweig, Products Liability in the Conflict of Lawe, 69 YALE L.J. 794, 801 (1960). 
these accidents will not give rise to guest claims. Some will not involve passengers; others will involve passengers who are not injured; and still others will involve injured passengers who cannot recover because they are married to, or are minor children of, the driver. But some accidents will injure guests who have standing to make a claim.

If these claims occur only infrequently, they will have practically no effect upon insurance rates. Actuarial techniques minimize the effect of any single claim. First, excess limits experience is not considered in deducing basic rates. A freakish $\$ 100,000$ claim has no more effect than if it were for only $\$ 5,000$. More than one year's experience is often used to set the state-wide rate level, and territorial rate levels are developed from three or five years' experience; therefore, infrequent events will not contribute any appreciable bias to the data when they occasionally occur. Finally, the credibility concept limits the effect of any particular claim. A single guest claim, then, would have practically no effect upon insurance rates. If it were against an insured from a territory with fully credible experience it would represent, at the most, one out of 1084 claims. ${ }^{44}$ Even if the average claim in the experience were $\$ 700,45$ making total losses at least $\$ 758,800$, and the guest claim exceeded basic limits, so that it was considered to be $\$ 5,000$, this would represent considerably less than 1 per cent of the experience; it would, therefore, affect the rate by less than 1 per cent. In most cases the guest claim would be close to the average, so that each guest claim would represent about 1/1084th of the experience. Eleven such claims would represent approximately 1 per cent of the experience, and would have a 1 per cent effect upon the initial rate calculations. ${ }^{46}$

Such miniscule factors are likely to be lost when, in the rate making process, the actuary rounds off his figures. Class $1 \mathrm{~A}$ basic limits rates, which are the basis for all other private passenger rates, are generally under $\$ 50$. Brooklyn has the highest in the nation, $\$ 119$; but in California the highest is $\$ 67$ for San Francisco. In Oakland, the next highest, the rate is $\$ 47$. Rounding off rates near $\$ 50$ to the nearest dollar can change the premium by 1 per cent or more. The average change for such rates would be .5 of one per cent. Most rates, however, are under $\$ 30$. In calculating the rate for Wilmington, Delaware, the indicated rate of $\$ 15.74$ was increased to $\$ 16$, a change of 1.6 per

44. Full credibility requires at least 1084 claims. See note 32 supra.

45. In fact, the nation-wide average basic limits bodily injury claim for private passenger cars in 1959 was $\$ 753$.

46. In territories with less experience the effect of one guest claim upon the indicated rate would be greater, but the weight given to that indicated rate would be less, thus decreasing its effect. If the experience included 271 claims, it would be $50 \%$ credible. Assuming that the claims averaged $\$ 700$ each, the total losses would be $\$ 189,700$. An excess limits guest claim, considered for rate making purposes as a claim of $\$ 5,000$, would represent about $2.7 \%$ of the experience. Since, however, the experience is given only $50 \%$ credence, it would affect the calculations by half of $2.7 \%$ or less than $1.4 \%$. An average claim would represent $1 / 271$ of the experience, but since the experience had only $50 \%$ credibility, its effect upon the rate calculations would be half of that, or 1/542. It would take, then, five or six claims to affect the initial calculations by one per cent. 
cent. Had the calculations yielded a figure of $\$ 15.51$ the rate would have been increased by over 3 per cent to $\$ 16$. It will be the exceptional case, therefore, in which a single, or even a few, guest claims will cause any changes in rates. ${ }^{47}$

On the other hand, if there are sufficient guest claims to affect the rate, regardless of the rounding-off practice, then the host should not be able to complain when his insurance premium reflects those claims. A substantial number of guest claims would indicate a pattern of travel into nonguest statute states. The indication would be that the host and his neighbors have taken, and no doubt will continue to take, a great many out-of-state trips into common law jurisdictions. From the actuary's standpoint, therefore, these trips are foreseeable. While the host may have no such trip planned when he buys his insurance, it is foreseeable that he will plan such a trip in the future. Of course, he may be atypical and stay home. If so, he is unlike his neighbors who have been lumped together with him in the rating territory. He might then have grounds for complaint - but they are wholly personal grounds which cannot be recognized if the insurance industry is to function. He cannot pretend to speak for his neighbors in complaining that insurance rates reflect guest claims. As far as his neighborhood is concerned those claims are "foreseeable and insurable."

The zone-of-risk analysis of the frolic and detour problem suffers from the same difficulty. Dean Smith hypothesized a business near Wall Street in Manhattan with customers in the Times Square area and a truck for making deliveries to them. Though the entrepreneur orders his truck driver to stay on Broadway and to avoid personal errands, he can foresee that the truck will occasionally return south by way of Seventh Avenue for reasons personal to the driver. He can even foresee that the driver may deviate as far north as Columbus Circle. He cannot foresee a trip to the Bronx or to Staten Island, so the zone-of-risk does not include upper Manhattan, the Bronx, or Staten Island. The entrepreneur, then, should not be liable for accidents in those places.

But, again, the entrepreneur's personal estimate of his zone of risk is irrelevant. The rate territory for commercial vehicles in lower Manhattan includes all of Manhattan, plus the Bronx and Brooklyn. In other words, the Wall Street entrepreneur pays his share of the total risk incurred by trucks garaged in those three boroughs. Even Manhattan enterprises which qualify for ex-

47. Of course, a few guest claims can still affect an occasional rate. They can be, like the proverbial straw which broke the camel's back, the cause for rounding up instead of down in the rare case where the indicated rate is very close to the $\$ .50$ mark. Assume, for instance, that the guest claim represents approximately one-tenth of one per cent of the experience, and that the indicated rate is $\$ 50.53$. Without this claim the indicated rate would be $\$ 50.48$. The claim would be the difference between rounding the rate up to $\$ 51$ and rounding it down to $\$ 50$. The chances of this happening, assuming that the claim represented one-tenth of one per cent of the experience and the rate was close to $\$ 50$, would be about one in twenty. The host's complaint would not be too telling, for he would have to urge that he was overcharged $\$ .52$ and that he had a right to be undercharged $\$ .48$. 
perience-rating pay part of that risk, unless they are so large that their experience is completely credible. Assume that each entrepreneur within the rating territory has formulated an idea of his enterprise's zone of risk. Occasionally a truck will stray beyond its zone and have an accident. Will this happen so infrequently that liability in such cases will not affect insurance rates? If so, the zone-of-risk concept is irrelevant. If, on the other hand, it happens frequently enough to affect insurance rates this extra-zone risk is insurable. Each entrepreneur will be surprised when he sees the report of an extra-zone accident, for, by definition, it happened beyond the zone of his expectation. But the actuary, if he were informed about the circumstances of all accidents in the experience he was studying, would not be surprised. He would know that accidents occurred with some regularity beyond the zone of normal business activity. ${ }^{48}$ Of course, an occasional accident would surprise even him. $\mathrm{He}$ might be blasé about a Wall Street-based truck piling up in Yonkers, but he would be somewhat surprised if the accident occurred in Albany. Yet, the same factors which made the accident surprising would make it ineffective in the rate making process. It would represent a miniscule part of the experience.

In short, an entrepreneur's a priori concept of his own zone of risk should not be a determining factor in the frolic and detour problem; this is so because his vehicle and those of his fellow entrepreneurs in the same rating territory are probably involved in accidents just beyond the boundaries of their respective a priori zones with sufficient frequency to make those accidents "foreseeable and insurable" from an actuarial standpoint. This concept requires a sophisticated approach to each enterprise's zone of risk-an understanding that each zone includes these accidents. However, even this sophisticated notion of the zone of risk may not be significant, for the number of accidents occurring beyond this extended zone will be so small in relation to the total number of claims against the enterprises grouped in the rating territory that these extra-zone claims, if honored, will have no appreciable effect upon insurance rates. Their effect will probably be obscured by the practice of rounding off the rates, so no entrepreneur could claim his insurance rate was unfairly increased by the payment of such claims. ${ }^{49}$

48. Though the analysis used here is the same as that used in discussing the guest statute the problem is complicated by the fact that instead of a simple geographical boundary (a state line), there is a complex boundary which is crossed whenever a truck leaves its particular zone of risk, even though it stays within the rating territory. The "zone" here is not merely the territory of Manhattan, the Bronx, and Brooklyn. It is the aggregate of each zone hypothesized for each entrepreneur. Thus, while a truck from the Wall Street-based business which strays into Brooklyn is still within the rating territory, and is within many other entrepreneurs' zones as well, it is beyond the zone of the risk, even from the actuary's standpoint, because it has left the zone of its enterprise.

49. This is true even if the entrepreneur qualifies for experience rating and the outlandish claim was against him. This would clearly be true if his rate were set entirely upon his own experience, that is, if his experience had $100 \%$ credibility. Then the analysis in the text would apply with very little change, except that the entrepreneur himself would soon have a sophisticated idea of his zone of risk. After a couple of years he would realize 
The same point could be made concerning the other uses to which the zoneof-risk analysis has been put. The risk of a producer's liability under foreign strict-liability products-liability law, as well as the risk of an automobile owner's liability under foreign owners' liability statutes, is either frequent enough to be "foreseen and insured," or is infrequent enough to have only a small, random effect upon rates. Either the risk is "foreseeable and insurable," or it is de minimus.

Another difficulty with the zone-of-risk analysis, particularly as it is applied to conflicts problems, is that it assumes that there is a measurable difference between risks in various jurisdictions. In the automobile field this assumption is valid. Rates differ from state to state, though how much of this difference reflects differing law is unknown..$^{50}$ Many other factors, such as congestion, highway design, and regional habits may be more important. Thus, it is diffcult to determine whether foreign law, though different, really imposes a different quantum of risk. ${ }^{51}$

But in the case of product liability there are no state-by-state rates except for the 38 special bodily injury rates in New York. ${ }^{52}$ Even if actuarial techniques were mechanically applied to the experience in Ohio, for example, there would be no reason to believe that the rates thus deducted would accurately represent the risk of Ohio law. After all, the nation-wide rates are demonstrably inaccurate for the classes with completely credible experience, and it is known that these inaccuracies are balanced by undeterminable errors in the other direction in the rates for classes with noncredible experience. Any attempt to calculate rates for any one state alone, of course, would have to be based upon experience with much less credibility, so that errors would be much more likely. In addition, if the experience of many classes were combined, so that at least the general rate level could be set according to credible experience, that rate level would still not reflect the peculiar risk of Ohio law. It would necessarily include losses in Ohio's tire industry, which are governed by the laws of many states in which the tire industry distributes, as well as the losses of Ohio's bakeries, which are rarely sued out of state. Furthermore, it would include food industries, which are subject to the Ohio strict liability

that "the damnedest things happen in this business." The few claims which were so farflung as to still shock him would represent such a small part of his experience that they would not materially change his rate. If, however, the enterprise had experience of less credibility, the entrepreneur might still retain a relatively naive concept of the zone of foreseeable risk. He might still be surprised at accidents which, taking the rating territory as a whole, did not involve unforeseeable deviations. However, since the credibility assigned to the enterprise's experience would be low, the effect that experience would have upon the rate charged would be small, and hence the effect of a frolic claim would be similarly decreased.

50. Peck, Comparative Negligence and Automobile Liability Intstrance, $58 \mathrm{MrcH}$. L. REv. 689, 723 (1960).

51. For instance, Professor Peck concludes that substituting comparative negligence for the common law defense of contributory negligence does not measurably increase automobile liability insurance rates. Peck, supra note 50.

52. Plus the few special rates mentioned in note 40 supra. 
rule, as well as nonfood industries, which are subject only to negligence and warranty law. Thus, it would not be possible to set accurate Ohio rates. No attempt has been made to do so. The rates charged to Ohio entrepreneurs and to most non-Ohio entrepreneurs, therefore, reflect an inaccurate apportionment of the nation-wide product liability risk.

Can, then, a non-Ohio entrepreneur claim immunity from Ohio's strict liability rule because he has not insured against a fortuitous application of Ohio law? Unless he is subject to a special state rate, such as the 38 bodily injury rates in New York, his claim is clearly invalid. He has paid for part of the Ohio risk, even though he is from a state with a different law. ${ }^{53}$

There is yet another difficulty with the zone-of-risk approach. It assumes that extra-zone activities are more hazardous. It may well be, for instance, that highway conditions, amount of congestion, etc., make accidents less likely in a neighboring nonguest statute state than in the host's guest statute jurisdiction. The added safety might offset the added risk of guest claims. Similarly, a Manhattan truck driver who frolics to Staten Island, a trip which involves an extended ferry ride and leads to less congested roads, may be less likely to have an accident than his fellow employee who takes the same amount of time for five personal errands within the zone of risk in lower Manhattan. In these cases it would not seem that the entrepreneur could claim that he had not undertaken to sustain the quantum of risk involved. He had provided for a greater risk than that which caused the loss.

\section{The Actuarial Importance of These Rules of Law}

Finally, even if the zone-of-risk analysis had validity, there is reason to believe it is not relevant to the particular rules of liability to which it has been applied, because they are not important in the process of risk administration.

Current insurance practice makes it likely that the driver of an automobile or truck is himself covered by the owner's insurance under the "omnibus clause." A judgment against the driver, then, is payable from the same fundthe owner's insurance-as if it were against the owner. ${ }^{54}$ The omnibus clause

53. Even if products liability rates were written upon a state by state basis, there would be some question as to whether the Ohio strict liability rule in food cases creates a unique risk. Twenty-one other jurisdictions have substantially the same law. Only sixteen, at most, have rejected it. The remaining fourteen American jurisdictions are, for the moment, uncommitted. Prosser, supra note 25, at 1107-11.

54. How would the zone-of-risk analysis apply to cases in which the insured owner lent his vehicle to another entrepreneur with a different zone-of-risk, and the bailee was covered by the omnibus clause in the owner's policy? Clearly, an accident within the bailee's zone of risk, but beyond the owner's zone of risk, should be within the omnibus coverage. In conflicts cases the combinations of difficulties are legion. A guest-statute state owner lends his car to a common-law state bailee who, with permission, takes a neighbor from the common-law state for a ride and injures him in a third, guest-statute state. A similar problem can also arise in the products liability field, since some manufacturers' policies include a "dealers clause," whereby wholesalers and retailers are also insured. See Gowan, Products Liability Insurance, 26 InsUrance Counsel J. 411 (1959), 
purports to cover anyone using the vehicle with the owner's permission. Permissive use is a vague concept, but it certainly covers the usual car rental case as well as the usual employee case. In some jurisdictions it will cover the employee even though he has deviated quite far from his assigned task. Quite clearly, the omnibus clause reduces the importance of owners' liability statutes. In some jurisdictions it may make the distinction between frolic and detour largely irrelevant.55

But even in those cases where the omnibus clause is not a factor, either because the owner is self-insured or because the jurisdiction construes the clause to exclude frolics, the vagarities of agency law probably have little important effect in master-servant cases. It is likely that juries pay little attention to such legal technicalities. They will rarely find that there was a frolic. Only in those cases which courts withhold from juries, and in a few others where juries find a frolic, will the limits of the scope of employment determine the issue. It is likely, then, that there is little difference between the actuarial burden of the owner's liability statutes, the omnibus clause burden in the more liberal states, and common law vicarious liability.

The same is probably true of the Ohio products liability rule making sellers of defective food liable without a showing of negligence.

[A]n honest estimate might very well be that there is not one case in a hundred in which strict liability would result in recovery where negligence does not. When a negligence action is brought against a manufacturer, the plaintiff is faced with two initial tasks. One is to prove that his injury has been caused by a defect in the product. The other is to prove that the defect existed when the product left the hands of the defendant. For neither of these is strict liability of any aid to him whatever. ... Once over these two hurdles, the plaintiff has a third task, to prove that the defect was there because of the defendant's negligence. This is by far the easiest of the three, and it is one which the plaintiff almost never fails. ${ }^{50}$

The Ohio rule, therefore, would probably have little effect upon product liability insurance rates even if an Ohio rate could be calculated with any degree of accuracy.

55. Most courts define permission to be consent to use at the time or place of the accident for an authorized purpose. ... Permission to use for one purpose does not imply permission to use for all purposes, but a reasonable deviation from route may be impliedly permitted. ... If a car is borrowed for purely social purposes, a general permission may be implied in fact to cover an extended use. ...

The minority merely requires permission in the first instance .... Any use thereafter is permissive even if the car is driven to a place or used for a purpose not contemplated by the owner. ...

If a master-servant relation exists . . permission is coextensive with 'scope of employment' in the majority jurisdictions ... . [In the minority jurisdictions,] no attempt is made to limit liability to the scope of the employment.

Automobile Liability Insurance-Permissive Use Under The Omibus Clause, 28 Texas

L. Rev. 719-20 (1950).

56. Prosser, supra note 25, at 1114. 
The importance of these rules from a quantum of risk standpoint is further minimized when the settlement process is considered. After all, few claims are taken to court; most are settled. Defendants will not be anxious to litigate if their only defense hinges upon the shadowy concept of "frolic and detour." Certainly the defendant in a poison food case will seek to avoid trial if his only defense is a claim that the defect was caused by an unavoidable accident. These defenses, then, will rarely be principal issues in contested cases. The defendant who can only rely upon such weak points will be anxious to settle. ${ }^{57}$ It can be assumed, therefore, that the main effect of these rules of law is to reduce the amount paid in settlement, rather than to reduce the number of claims paid. While they might cause some hundred thousand dollar claims to be settled for fifty thousand, and some five thousand dollar claims to be settled for four thousand, it is probable that one hundred dollar claims will not suffer much reduction because of these rules of law. Even if these doctrines were applicable to enough cases to affect the rates, their effect upon basic limits rates might be nil, because so much of the basic limits experience involves small claims which are not the subject of spirited bargaining at settlement. On the other hand, it is unlikely that rules of law peculiar to some jurisdictions have any effect upon excess limits rates because these rates are based upon differentials which are uniform for most states, including those states which do not honor such rules. The percentage of excess limits experience affected by these rules, then, is likely to be small..$^{58}$

We must conclude, therefore, that these zone-of-risk theories of enterprise liability overlook the actuarial realities of the administration of risk. They rely upon an entrepreneur's hypothetical estimate of the risk in the light of his foresight, rather than upon the actuary's estimate of the risk based upon hindsight. Furthermore, they assume that certain factors increase the quantum of risk, which may be contrary to fact or, at least, not measurably true.

\section{The Logrcal Validity of the Zone-of-Risk Approach}

There is also a logical fallacy in the zone-of-risk approach. This theory would have the law decide which losses should be charged to the entrepreneur by discovering what losses he has provided for. But the entrepreneur provides for the losses the law dictates he must bear. The theory, then, is tautological. The rules of liability are to be dictated by insurance practices which are, in

57. See Peck, supra note 50 , at 727 , concerning the insurance adjustment practices which reflect the fact that contributory negligence, though doctrinally a defense, cannot be relied upon at trial.

58. Of course, unique rules of law could result in a special excess limits table for the state that has them. Whether this will happen depends upon the importance of the rule. If the rule enhances the awards in all cases, it may affect the rates. If it only applies to a few cases, it must greatly enhance the awards in those cases or its effect will be undetectable. Finally, if its effect is apparent only in large cases, it will be undetectable because of the low credibility of experience involving large claims. 
turn, dictated by the rules of liability. ${ }^{59}$ All that can be concluded from such a premise is that whatever is, should be.

Specific recommendations which claim to be deduced by this method, then, turn out not to be based upon it at all. For instance, Professor Ehrenzweig is quite clear that the entrepreneur should never be permitted to defend against the application of the law of his domicile or place of business. This law, to say the least, is "foreseeable and insurable." But the entrepreneur theory does not necessarily lead us to this conclusion.

Let us assume, for instance, that there are specific product-liability rates for meat packers in Ohio and Kentucky and that, because Ohio imposes strict liability while Kentucky does not, the rate for Ohio risks are higher than those of Kentucky risks. ${ }^{60}$ Let us assume further that two packers each attempt to serve the Cincinnati-Louisville area. Each sells 60 per cent of its product in Cincinnati and 40 per cent of its product in Louisville. The only difference between these two enterprises is that one's plant is located in Louisville, the other's in Cincinnati. It is quite clear that the Louisville packer has significant contact with Ohio. Sixty per cent of his product is sold there. If he sells tainted meat, sixty per cent of his victims can be expected to be in Ohio. $\mathrm{He}$ should, therefore, provide for the harsher burden of Ohio law, as Professor Ehrenzweig points out. However, Professor Ehrenzweig would hold the competing Cincinnati packer to Ohio law for 100 per cent of his product, even though 40 per cent was sold in Louisville and therefore 40 per cent of his victims would be in Kentucky. This appears to be an arbitrary position, since, except for the location of their plants, the two enterprises are exactly the same. Why can't the Cincinnati packer demand his share of the lesser burden of Kentucky law? The products-liability question must be distinguished from certain others which are clearly dependent upon the location of the entrepreneur's plant. For instance, Kentucky's policy toward employees is paramount for the Louisville packer and irrelevant to the packer in Cincinnati. The Cincinnati enterprise, which creates employment in Ohio, cannot claim that its unemployment compensation burden should be partially governed by the law of Kentucky. The location of his plant in Ohio is determinative. However, products liability governs legal relationships between buyers and sellers in the

59. "In other words, it is not true that a risk shifting device can be used only in case of liability for negligent 'detours.' It has such flexibility that it can be used whenever a court decrees liability. That is to say, its limits are set by rules determining liability, and courts by their decrees and judgments make those rules." Douglas, supra note 4, at 591 .

60. This assumption is not only false because products liability rates are written country wide, but because, even if they were not, insurance practice considers only the location of the insured enterprise, not the situs of the injury. Thus, if an automobile garaged in New Jersey has an accident in California, a claim against the driver of the New Jersey car will be part of the New Jersey experience, not part of the California experience. It is, after all, indicative of the kind of claim which insurance companies doing business in New Jersey must pay. In the textual hypothetical it is assumed that claims arising in each state have been segregated according to state, and that a rate for each such class of claims can be deduced. 
market. Why is the extent of the market not regarded as determinative, and the location of the plant considered fortuitous ? ${ }^{\text {B1 }}$

The reason Professor Ehrenzweig did not take this position was that he was not reasoning from an economic premise. He knew that if the law was otherwise, entrepreneurs could adjust to it. He knew that most Kentucky claimants would come to Ohio to sue the Cincinnati packer. He knew, moreover, that Ohio courts could consider that that packer had a meaningful contact with Ohio and that Ohio law should govern in such cases. The packer and his insurer, aware of Ohio law, could foresee this added burden, not only as to Ohio sales but as to Kentucky sales as well.

But, given enough advance notice, the entrepreneur can adjust to a great number of additional costs. Should the concept of "frolic" be abandoned? To some extent it has been in states which have enacted owners' liability laws; and owners have adjusted to it by insurance. Should an entrepreneur's liability for injuries to persons upon his premises be extended to include strict liability for all injuries to persons on the sidewalks abutting his premises? He could insure against such liability also, if given advance notice. In short, all that the risk spreading branch of the entrepreneur theory points out is that, within limits, enterprises may insure any risk if given sufficient notice. Extensive risks will have actuarial credibility which, after a time, will permit their evaluation so that the cost of such risks can be assessed. Risks without credibility will probably be slight enough so that no injustice will result from the fact that they cannot be assessed; provided, of course, that they are similar enough to determinable risks to be within the coverage of standard insurance policies.

This does not mean that the risk spreading branch of the entrepreneur theory is worthless. This simply means that its place in the theory of enterprise liability is limited. It is a functional statement, rather than the sole justification of enterprise liability.

\section{Risk Spreading and the Rationale of Enterprise Liability}

Dean Smith stated that the function of enterprise liability is "[T]o include in the costs of operation inevitable losses to third persons incident to carrying

61. A similar argument could be made concerning a Hartford car rental agency whose U-Drive-It cars invaded Massachusetts with some regularity. If we assume that the Connecticut burden is more onerous than the Massachusetts burden, the question arises as to why the Hartford agency cannot claim the benefit of that lesser burden for the mileage its cars travel in Massachusetts. It is, after all, selling a certain number of miles of Massachusetts travel each year, and it should only have to underwrite the cost of those miles as determined by the law of Massachusetts. Professor Ehrenzweig does not agree.

[Connecticut] law was... the law properly applicable to any accident caused by one of the agency's cars kept, rented, and insured in Connecticut; and any more lenient laws prevailing elsewhere could not benefit the defendant. Wherever injured or resident, the plaintiff in the Connecticut court can rely on the lex fori which will not admit of any exceptions.

Ehrenzweig, Vicarious Liability in the Conflict of Lawes, 69 YALE L.J. 978, 986 (1960). 
on an enterprise." His idea was seconded by many, including Talbot Smith, who observed that "business must pay its passage." But what losses are properly considered "incident to carrying on an enterprise"? What costs are part of a business' "passage"?

The language used implies an analogy to other business expenses. As businesses must pay for capital, material, and labor, so must they pay for the lives, bodies, and property they inadvertently consume. This analogy to economic principles, however, conceals value judgments, similar to those involved in other branches of the law, which dictate the extent to which businesses should pay for the capital, material, and labor intentionally devoted to an enterprise. Technology requires the barest union of labor and materials. While capital goods are necessary, "capital" is not. All that is required is some technique to feed and maintain the labor force which creates capital goods, given the fact that the product of that labor will not be immediately useful for consumption. Labor, furthermore, need only be paid enough to continue working. These are the technological minima; and they are completely unsatisfactory on nontechnological grounds. Hence, we embrace a market economy, including capitalistic methods of obtaining capital goods, instead of forced labor or collective economic organization. But the economic forces of even this market economy lead to undesirable results, and for humanitarian reasons (though not without some economic justification) we have mitigated the rigors of a free market economy with minimum wage laws, wages and hours laws, child labor laws, etc. And it is upon these same nontechnological and humanitarian grounds that we approve of enterprise liability. In other words, those losses which enterprise liability seeks to repair are not losses which need be repaired to assure the maintenance of production. Moreover, though these losses have some economic effect, since their immediate victims are removed from the ranks of consumers, their repair is no more important to the operation of a market economy than is the repair of losses from natural causes. ${ }^{62}$ These repairs are made, then, for humanitarian and moral reasons rather than for technological or economic ones.

The entrepreneur theory also attempts to gain credence by invoking the concept of commutative justice. Though the entrepreneur himself is relatively blameless, his enterprise entails a certain amount of risk, and it is proper to place the burden of this risk upon him in the first instance, because he can pass it on to his customers. They benefit from the risky endeavor and should therefore suffer the burden of the more or less inevitable accidents which arise from that activity. ${ }^{63}$ This view suffers from two difficulties. It assumes that the in-

62. Douglas quotes Dean Smith's observation that employers should not be liable for their employees' acts which are unconnected with the enterprise "because it would result in including in the cost of production an item which economically does not belong there," text accompanying note 15 supra and observes that this is no answer. "It depends on the definition of 'economically.'" Douglas, supra note 4, at 593 n.24.

63. Professor Ehrenzweig appears to have adopted this view when he quotes Justice Traynor with approval to the effect that products liability is justified because "the risk 
juries are somehow attributable to the enterprise activity; and it involves economic assumptions of doubtful validity.

Turning first to the economic assumptions, it is probable that customers will not suffer the entire burden of enterprise liability. Prices, after all, are determined by the interaction of supply and demand. If demand remains stable, an industry cannot raise its prices without also decreasing its sales. The extent of this decrease depends upon the slope of the demand curve. If it is relatively steep, changes in price will be accompanied by relatively small changes in volume. If the curve is relatively flat, a slight rise in price will cause a large loss of volume. Depending upon the industry's demand curve, then, the burden of enterprise liability will be allocated between the industry and its customers, the former suffering some decrease in volume, the latter some increase in price. ${ }^{64}$ Insofar as there is a decrease in volume, the burden is suffered by the entrepreneurs, laborers, investors, and suppliers involved.

The distribution of the industry's part of the burden among its constituent groups depends upon a myriad of factors. Highly competitive industries can only decrease production by driving their weakest enterprises out of business. Until this is accomplished, no price rise will be possible and the profits of all enterprises will be less. Whether this will happen, and when it will happen, will depend in turn upon the ease with which plants can be converted to other kinds of production and upon whether the weak enterprises are financed in the main by stock or debt. When these enterprises finally do leave the industry, the remaining businesses may return to normal, but the companies which have failed, together with their employees, suppliers, and investors, will suffer the main effect of the burden. If, on the other hand, the industry can intentionally curtail production, all enterprises will suffer a reduction in profits. The amount of this reduction will depend upon the amount of fixed costs which must be spread over a smaller volume of business, the ability of labor to resist attempted cuts in payroll, and similar factors. Other factors are also relevant: the condition of the money market, the ability of suppliers to find alternative markets, etc.

It must also be observed that the customers' side of this problem is equally complex. If the industry's customers are also business enterprises, that part of the burden passed on to them in the form of higher prices must be distributed among their owners, creditors, employees, customers and suppliers in the same manner as the original entrepreneurs spread the initial burden.

In short, the ultimate distribution of the enterprise liability burden cannot be the subject of easy generalizations. Assuming for the moment that the bur-

of injury can be insured by the manufacturer and distributed among the public as a cost of doing business." Escola v. Coca Cola Bottling Co., 24 Cal. 2d 453, 462, 150 P.2d 436, 441 (1944), quoted in Ehrenzweig, Products Liability in the Conflict of Lazes, 69 YalE L.J. 794, 798 (1960). This appears to be the position of Dean Smith, Larson, and Farper and James, note 9 supra. But as to Harper and James, see note 66 infra.

64. See Plant, Strict Liability of Manufacturers for Injuries Cansed by Defects in Products-An Opposing Viez, 24 TENN. L. Rev. 938, 947 (1957). 
den is significant, so that entrepreneurs react to it rather than suffer it unnoticed, ${ }^{65}$ all that can be said is that entrepreneurs probably bear part of it themselves, that they spread part of it to their employees, creditors, suppliers, and customers, and that the members of each of these groups spread it, in turn, to those with whom they have important economic relations.

It might be thought that this does not mean that the commutative justice argument is wrong but, on the contrary, shows how right it really is. Customers are not the only beneficiaries of enterprise. Laborers, suppliers, investors, and owners also benefit. If they did not also suffer part of the burden of industry-induced accidents, there would be no commutative justice. The fact that they too bear part of the burden indicates that there is commutative justice. ${ }^{66}$ On close examination, however, this argument appears faulty. The amount of benefit a one company town derives from that company when its plant is producing at capacity does not vary with the shape of the supply and demand curves which govern the company's market. Yet the shape of those curves does, in part, determine the impact of enterprise liability costs on the amount of production at the plant. Similarly, two competing entrepreneurs may each be equal beneficiaries of their respective enterprises, though the labor force in one enterprise is organized and the other is not. The union's ability to resist cutbacks in payroll costs (through contract provisions for a guaranteed minimum wage, severance pay, call-in pay, featherbedding, etc.) may make the organized entrepreneur suffer more from a loss of volume than his unorganized competitor. The commutative argument, therefore, relies upon very rough justice indeed.

Of course, this roughness in principle may not be mirrored by a roughness in fact. The cost of enterprise liability may be small enough so that it has only minor economic consequences and there is, therefore, little need for fine, exact adjustments. But this is practically a return to Baty's deep pocket argument. In place of the entrepreneur's deep pocket we have substituted the pocket of

65. Though economists generally assume that the market is responsive to all stimuli, one can wonder whether or not this is true. It seems likely that some items are so small that they do not affect the price mechanism. Products liability rates, for instance, are quite small in some industries, even in those industries with substantial claims experience. The non-New York rate for restaurants at maximum limits is $\$ .4592$ per $\$ 1,000$ of sales. A canner of meat or seafood pays $\$ .4624$ per $\$ 1,000$ of sales. These rates, which are less than .05 of one per cent of the market price, may be too small to have an effect upon prices. If the canner's rate does affect prices to the wholesaler, he will be unable to pass all of that burden to the grocer. That amount which he may theoretically be able to pass to the grocer: may be too small, in fact, to actually pass on.

The above rates are stated to the hundredth of a cent, even though basic limits rates are rounded off to the nearest cent, because the excess limits factors have two decimal places. Some companies round off their final rates, others do not.

66. Harper and James appear to be of this opinion. They state that the entrepreneur passes the burden on to the "beneficiaries" of the enterprise. They are explicit on the point that this includes employees as well as customers. They do hot specify any other class, but the point is implicit in their use of the word "beneficiaries." 2 HARPER \& JANIES, ToRTS $1364 \mathrm{n} .12$ (1956). 
every man. His pocket may not be deep in absolute terms, but it is in relation to the amount taken from it. Commutative justice dictates that some amount be taken and some is. The proper amount is so small that it is really not unjust if twice as much is taken. But, if taking twice as much will not cause unjust impoverishment, by the same token there would be no unjust enrichment if nothing were taken. It follows that there is no strong economic basis for the commutative justice argument.

\section{The Allocation of Losses Among Various Enterprises}

Finally, many justifications for the entrepreneur theory, including the commutative justice argument, are based upon the assumption that the enterprise has, in some sense, caused the loss in question. This is not thought of as direct, physical causation (except in the unusual case), but is thought of as a matter of risk making. However, this is a difficult concept to nail down, for few accidents occur in the context of a single institution. The entrepreneur's workman is also a household's breadwinner. The victim of a meat-packer's mistake was poisoned in his employer's lunch room, at a restaurant where he was a patron, or in his own home where he consumed the stock of the household larder. A change in the practices of these other institutions might have avoided the injury. Insofar as the injuries could not be avoided, these other institutions might be charged with the loss-shifting and loss-spreading function.

The law comes close to recognizing this fact explicitly in the borrowed servant cases, and in those workmen's compensation cases where the employee is injured in the course of his employment by an outsider. In those cases the employer is liable, but the outsider is also subject to a "third party" action. ${ }^{.7}$

But this double institution problem also occurs in losses involving only one business, the other "enterprise" being the injured person's household. The trichinosis cases are an obvious example. Trichinae-free pork can be assured either through proper feeding methods or by prolonged freezing of fresh pork. Sufficient cooking will make contaminated pork wholesome. Most of the cases have considered the disease to be "incident" to the kitchen, rather than to business practice. 08

This line of reasoning can be taken even further, as it was when Chief Justice Shaw apologized for the abominable fellow-servant rule in Farwell $v$. Boston \& Worcester R.R. ${ }^{69}$ Farwell had lost his hand due to the negligence

67. 2 Larson, Workmen's Conpensation ch. XIV (1952). Of course, this is an incomplete recognition of the point, because the employer or his insurer is subrogated to the employee's rights in the third party action, and is enabled thereby to recoup his payment of compensation benefits. Similarly, in the borrowed servant cases the law attempts to choose between the two enterprises involved, rather than seek contribution from both.

68. Dickerson, Products Liabitity and the Food Consumer 190-211 (1951); Eisenback v. Gimbel Bros., Inc., 281 N.Y. 474, 24 N.E.2d 131 (1939) (restaurant liable to patron on breach of warranty, but restaurant's suit over against its supplier dismissed because "a party cannot recover for a loss that he could have averted by the exercise of due care"). Contra, MicSpedon v. Kunz, 271 N.Y. 131, 2 N.E.2d 513 (1936).

69. 45 Mass. ( 4 Met.) 49 (1842). 
of another workman. Institutionally, he represented the overlap of two enterprises. On the one hand, he was laboring to be a good provider for his household. On the other hand, he was working for the railroad to help it in its task as a common carrier for the benefit for shippers and consignees in Massachusetts. Justice Shaw did not think of the case in these exact terms, but his opinion reflects the multi-institutional aspect of the case. "These are perils," he observed, "which . . . are perils incident to the service, and which can be as distinctly foreseen and provided for in the rate of compensation as any others. To say that the master shall be responsible because the damage is caused by his agents, is assuming the very point which remains to be proved."70 Having thus questioned the relevancy of the railroad-institutional context of the accident, Chief Justice Shaw could find no justification for allocating the loss to the company. He apparently viewed the plaintiff in his household-institutional context, where he occupied the status of breadwinner: "[I]t is the ordinary case of one sustaining an injury in the course of his own employment [as a breadwinner?], in which he must bear the loss himself, or seek his remedy, if he have any, against the actual wrong-doer."71 Plaintiff's injury, a crushed hand, was typical of life in general. Plaintiff's wife could have suffered it in the clothes wringer. He or his children could have been so injured by the family horse. Chief Justice Shaw was content to leave the burden of the loss upon the household, the institution which traditionally cares for the sick, the infant, and the infirm. The injury, he stated was "the result of a pure accident, like those which all men, in all employments, and at all times, are more or less exposed; and like similar losses from accidental causes, it must rest where it first fell, unless the plaintiff has a remedy against the person actually in default ...."72

Now that insurance is readily available and the household can be thought of as an enterprise, as it is in connection with automobile risks, we can make a better case for Chief Justice Shaw's position. Plaintiff's injury was incident to his position as a breadwinner for his household. It was typical of the risks of that position. Furthermore, it was not atypical of other household risks. Nonbreadwinners suffer similar injuries. The household, being the primary institution for care, has the primary responsibility for this burden. It can spread the loss among its members. If it is oppulent or has a number of breadwinners, it is in some sense self-insured. If not, it can insure.

Contrast current thinking concerning workmen's compensation. Even horseplay accidents are compensable, as indeed they should be. The entrepreneur theory has been thought by one author to justify this result. $\mathrm{He}$ said:

Clearly, fooling at work is incidental to it, and a hazard of men working together. The more recent and better rule is to allow an award for an injury resulting from horseplay, even to aggressors, where the injury is a

\footnotetext{
70. Id. at 57 .

71. Id. at 59 .

72. Ibid.
} 
by-product of associating men in close contacts, thus realistically recognizing the "strains and fatigue from human and mechanical impacts." "73

The same reasoning might apply to automobile injuries on the Labor Day weekend, when employers give most employees three days to escape further the "strains and fatigue" of their employment. Highway congestion, accompanied by foreseeable carnage, is induced by this business practice. Yet could one argue that the injuries should be compensable under workmen's compensation? It may be answered that such injuries are handled by other means, by making each car owner an entrepreneur who must insure. But that is the very question to be decided. It can be decided either way. It is, perhaps, some answer to say that the practice of insurance does lessen the social problem. But automobile liability insurance will not compensate all victims of automobile accidents. Negligent drivers and members of their immediate families cannot recover. Blameless victims who are injured by uninsured motorists cannot recover. These groups must look to their own medical and accident insurance, which is less common than liability insurance, for recovery. Yet it is doubtful that society is ready to extend workmen's compensation coverage to include all automobile injuries on national holidays. These losses have been allocated to the household enterprise, which must bear that burden until such time as it is encompassed by more inclusive welfare legislation.

Chief Justice Shaw, in allocating the risk of industrial accidents to the household, wrongly assumed that the employee had been compensated for the risk by the wage rate. Actually, the contract of employment reflects the bargaining power of the parties, and a greater risk will not increase the employee's bargaining power unless it is so great that it frightens away the mass of applicants, causing a labor shortage for the job in question. But since Shaw's opinion, the development of organized labor has made compensation for industrial accidents a bargainable issue. Indeed, many unions have won concessions on this point. ${ }^{74}$ Yet few would hold that because employee welfare has become a bargainable issue, Shaw's position should now be adopted. Workmen's compensation has allocated some of the burden of industrial accidents to business enterprise, which must bear that burden until, again, such time as this risk is encompassed by more inclusive government welfare schemes.

It might be objected that the above is all based upon carefully chosen examples. The industrial accident involves one who is performing the bread-

73. Horovitz, The Litigious Phrase: "Arising Out of" Employment, 3 NAACA L.J. 15, 57-58 (1949), quoting Harford Acc. \& Indem. Co. v. Cardillo, 72 App. D.C. 52, 58, 112 F.2d 11, 17 (1940) (Rutledge, J.).

74. Most notable is the United Mine Workers Welfare and Retirement Fund, financed by a royalty upon each ton of coal mined in the organized soft-coal industry. In the first nine years of operation it had a total income of $\$ 882,423,780$. It payed almost $\$ 330,000,000$ for pensions, over $\$ 246,000,000$ for hospital and medical care, over $\$ 105,000,000$ for cash aid to disabled miners, and almost $\$ 76,000,000$ for aid to widows and survivors of miners. 36 L.R.R.M. 187-88 (1955). See also 46 L.R.R.M. 319 (1960). For a recent study of health plans, see Garbarino, Healtit Plans and Collective Bargaining (1960). 
winning chore for the household while working for his employer. The third party action involves an employee performing a chore for his employer when injured by another. The trichinosis cases involve one who is the beneficiary of the household kitchen, a central household function, when he is injured by pork which was sold in a contaminated condition. A great number of accidents occur in cases which do not lie so near the intersection of two institutional patterns. For instance, if a taxicab jumps a curb and injures a child playing on the sidewalk, the child's household duties did not play an important role in causing the accident. But even in this case the accident would have been avoided if the child had not been permitted to play near the street. The causation argument, after all, relies upon the concept of risk, rather than the concept of physical causation. The question then becomes: What institutions have the duty to minimize risk? The taxicab company placed its cab upon the street, as it had the undoubted right to do. The household permitted the child to play near the street, which was also proper. But both of these practices increased the risk. The allocation of the loss to one or the other of these institutions involves more than finding the risk-increasing institution; it involves a judgment as to which of the two has the greater duty to reduce risks. ${ }^{75}$

It appears, therefore, that the general consensus in this area is determined not only by factual observations of risk increasing behavior, but also by our judgment concerning both the capabilities and proper role of the institutions involved. This judgment both dictates our goals and limits our sense of relevancy.

For instance, it is generally observed that business enterprise liability is spread to its customers; but no significance is attached to the possibility that household enterprise liability might be similarly spread. Yet, automobile insurance premiums are part of the household's costs; they are reflected in the cost-of-living index. ${ }^{76}$ Organized labor has some power to pass changes in the cost of living on to business enterprise. Escalator clauses do this automatical-

75. This passage ignores the negligence standard by which, according to current doctrine, the law attempts to decide which enterprise should bear the financial burden of the child's injury-the taxicab company or the household. If this question is to be looked upon merely as a financial matter, as the zone of risk theory intimates, the negligence standard has little applicability. That standard measures individual blameworthiness. Since each of the two estates has a number of beneficiaries, a standard which applies only to individuals seems irrelevant. Of course, in some cases the fact that one institution contains a blameworthy individual should be determinative, regardless of financial considerations. Even so, the negligence standard of individual conduct may not be proper. See text at note 86 infra.

76. Automobile insurance premiums represent .96 of one per cent of the cost of living index. U.S. Dep't of Labor, Technigues of Preparing Major BLS Statistical Series, Bull. No. 1168, at 75 (1952). Research has not revealed what fraction of this is liability insurance and what fraction is collision, fire, theft, and other automobile insurance. Certainly it is a large fraction, though it may be less than half. In any event, the fraction of the household's budget which is spent upon automobile liability insurance probably exceeds, or at least is not substantially less than, the fraction of business budgets spent for products liability insurance. See note 65 supra. 
ly ; and even where such clauses do not exist, it can be assumed that the militance of industrial unions varies with changes in the cost of living of their members. In some sense, therefore, employers help spread the risk of their employees' personal tort liability. Insofar as Labor Day automobile casualties receive recompense, employers ultimately pay. Business payrolls are the ultimate source of payment for household liability insurance premiums.

If the above observations do not ring true, that is in part due to the fact that they run counter to the general consensus concerning the proper role and scope of households as compared with business institutions. Business enterprise is generally considered to exist merely for the purpose of production. -Any other values to which it may give rise-pride of craftsmanship, successful careers, good companionship, etc.--are thought to be secondary. On the other hand, the household is generally considered to be the institution in which one lives the good life, insofar as that is possible. This is thought to be true even for the breadwinner who spends almost half of his waking hours at work rather than at home. ${ }^{77}$ The economic functions of the household are, then, given a lesser priority than the economic functions of business enterprise. Furthermore, great importance is attached to the decision-making function of business management, and it is thought to be subject to more public regulation than is the decision-making function of household management. Thus, when a loss occurs under circumstances involving both a household and a business, as in the taxicab-child example, we are more willing to attribute the loss to the business than the household, though the loss in that example was as typical of raising a child in a modern, urban environment as it was of running a taxicab business. Both institutions could insure and thus avoid the shock of the loss, but we prefer that the burden of insurance be a cost of business rather than a direct diversion of funds from the estate dedicated to the good life. Moreover, we are more willing to attempt to induce a change in business practice than a change of household practice. We feel, therefore, that if this risk can be minimized, business should do it. This leads to a concept of institutional fault as distinguished from personal fault.

Leave aside the relative blameworthiness of the individuals who were proximate to the accident-the business servant and the injured member of the household. Compare only the relative blameworthiness of the management of

77. By this implied criticism of our attitudes I do not wish to intimate that the noxious, unpleasant, but necessary, tasks of industry can be made pleasant or fun, or that all employees can learn to love their companies. This is no more possible than it is possible to make housework intellectually rewarding or to eliminate unhappy marriages. But when something is done to brighten the home, as for instance, the purchase of a hi-fi set, it is done in the name of the better life. On the other hand, the playing of music over a factory's public address system is more often justified in terms of improving efficiency, much as music in a hen-house is said to increase the production of laying hens. The personnel manager may hail the playing of music because it will help improve employee relations. But the company's concern for good employee relations is not primarily based upon the fact that friendship graces the good life. The company seeks good employee relations to cut down personnel turn-over and to decrease labor unrest, thus increasing production. 
the two institutions. Though each may have failed to take measures which might have reduced the risk, we are likely to find the business management more at fault, for business management is generally thought to be more the subject of public regulation; and we are more willing to impose standards of responsibility upon it. ${ }^{78}$

These attitudes were formed as the modern technological age grew out of a prior, pastoral way of life. On the one hand, the newer business institutions were considered to be in some sense interlopers. They had to accommodate themselves to the older institutions already upon the scene, including the household. On the other hand, the new dangers of an industrial society were thought to be different in kind from the age-old accepted dangers of disease, farm accidents, etc. New dangers are often disassociated from similar old ones. The recent increase in commercial air travel, for example, has given rise to special air travel life and accident insurance; this insurance finds a ready market among those who have no great desire to increase their general accident and life insurance coverage. Similarly, industrial accidents, automobile accidents, etc., have been thought to create new problems rather than merely to aggravate old ones. When these attitudes were first formed, insurance was not generally available and households were not affluent. The new social problems these losses were thought to present could not have been left to household devices. They were allocated to the more affluent business enterprises associated with them. This, in turn, helped formulate our concept of the proper role of business; thus establishing norms which are now unconsciously invoked whenever we consider these problems. ${ }^{79}$

78. Professor Keeton has investigated this general attitude and has concluded that it includes a consensus that an entrepreneur who embarks upon a legal, beneficial calling is nevertheless considered to be at fault, in the moral sense of that word, if he does so without the ability or intention of paying losses attributed to his enterprise. Keeton, Conditional Fault in the Law of Torts, 72 Harv. L. Rev. 401 (1959).

79. Even the concept of the proper function of the entrepreneur may be, in large part, the result of particular industrial developments. Dean Smith hypothesizes a man, $A$, who decides to enter the grocery business, borrows money from banker $B$, and rents a store from landlord $C$. Though neither $A, B$, or $C$ are judgment proof, he concludes that $A$ should bear the burden of enterprise liability. $A$ has control of the business. Neither the lease nor the promissory note give $C$ or $B$ such powers. Smith, supra note 1, at 460-61. If, however, instead of the grocery business Dean Smith had picked maritime shipping in his example, he might have arrived at a different conclusion. Admiralty law holds the ship responsible, which is merely another way of stating that the judgment will be executed against the ship, and that its owner will be the one who suffers the main burden of liability. Had $A$ decided to enter the maritime shipping business, and had he rented a ship from $C$, the parties would understand from the start that $C$ was primarily liable for losses legally attributable to the enterprise. A demise charter, which is functionally comparable to a lease, provides that the charterer (lessee) arrange indemnity coverage which will protect the owner-lessor from such liability. However, demise charters are rarely used, except by governments to obtain shipping or to put to use ships they own. Private parties usually use time charters, which provide that the vessel will be at the disposal of the charterer and sail at his bidding but the captain and crew will be hired by the owner. See Gilmore \& Black, Admiralty 204-19 (1957). In other words, the lessor of a sea- 
These norms are now so strong that it would not be thought desirable to reallocate the burden of the losses. Even though insurance is now available and households are generally affluent enough to afford the premiums, the norms require that business enterprise liability for such losses continue. Indeed, the norms are so well accepted that enterprise liability is still being extended to losses not easily distinguished from those which first molded the consensus. In workmen's compensation the extension has been from accident to occupational disease, from injuries suffered while doing assigned tasks to horseplay injuries innocently suffered, and then to horseplay injuries suffered by aggressors. A trend in the opposite direction would do violence to the established norms of business responsibility. And the problem of automobile accidents, which often do not involve any business institutions but only family cars, has been handled by analogy. Further enactment of owners' liability laws and a trend toward the family car doctrine were avoided by the general insurance practice of including an omnibus clause in passenger car policies. Now the problem of the uninsured automobile is being tackled with financial responsibility laws, unsatisfied judgment funds, and compulsory insurance.

All of this may be submerged when we seek grander solutions to the problem of shock losses in general. As welfare legislation expands to include medical care, the importance of this branch of law will certainly decline. ${ }^{80}$ But the concepts which it has helped create will certainly continue long after, affecting the growth of other fields of law. These concepts have already spilled over into the labor relations field in the legislative repudiation of the Hearst case. ${ }^{81}$

\section{The Cumulative Reasons for Enterprise Liability}

If enterprise liability is understood to be an outgrowth of current attitudes toward business and household institutions, then it must be considered in the

going vessel understands that his function is something more than an investor. He does not expect to relinquish complete control over the vessel. The fact that he cannot relieve himself from legal responsibility for enterprise liability, therefore, accords with his expectation. Any attempts to change the law in this regard would run counter to established norms of the industry and upset present, efficient working arrangements.

80. See Clarence Morris, Torts 344-45 (1953). The assumption that we will seek grander solutions to this problem is not based upon any feeling that the present solutions are inadequate in the areas where they now operate. Undoubtedly they are inadequate in many respects. But, even if these shortcomings are repaired, general welfare legislation will probably be enacted to cure other social evils. These schemes will be comprehensive enough, however, to cover those now compensated by enterprise liability. A federal medical plan, if enacted, will probably cover the medical expenses of traffic victims as well as cancer victims. A college scholarship program can provide an education for the son of a breadwinner who was killed in an airplane crash as well as the son of a man who has deserted his family.

81. National Labor Relations Board v. Hearst Publications, Inc., 322 U.S. 111 (1944) (reversed by the Taft-Hartley Act $\$ 2(3), 61$ Stat. 137 (1947), 29 U.S.C. $\$ 152(3)$ (1958), excluding "independent contractors" from the definition of "employee"); see Steinberg \& Co., 78 N.L.R.B. 211 (1948), enforcenent denied, 182 F.2d 850 (5th Cir. 1950). 
light of the many recognized functions of those institutions. The ability of those institutions to spread costs is only one recognized function. Each institution is considered also to have a certain amount of sovereignty within a limited sphere. Since managerial decisions can prevent losses by reducing risks, the preventative function of enterprise liability is also important.

Of course, it does not have a preventative function in all contexts. Artemus Jones has a cause of action, though nothing can be done, or is expected to be done, to prevent his suffering inadvertent defamation. ${ }^{82}$ Moreover, in many cases the effect of enterprise liability may appear to be unnecessarily cumulative. Drivers who do not fear for their own safety are not worried by employer wrath, the danger of liability, or insurance cancellation. ${ }^{83}$ Industrial accidents interrupt production, an expense to be avoided whether or not liability attaches. Poisoned customers detract from a product's good will. These factors decrease the need for legal accident deterrents, and they indicate that the law cannot claim first place among the ranks of deterrent forces. But that does not mean that enterprise liability has no deterrent function.

An unimportant case, Robbins $v$. Thies, ${ }^{84}$ will illustrate the point. Plaintiff was injured by a power company's wire, charged with 2400 volts, which was down on the road. The wire had been knocked down by an automobile accident in which one of the cars had hit the utility pole. The pin, which attached the wire to the pole, had been badly weakened by rot. Shortly after the accident, the operator of the substation which supplied electricity to the downed wire was notified by phone, but the wire remained charged for some time thereafter. Plaintiff was driving down the road when he noticed the accident, stopped to give aid, and was injured when he came in contact with the live wire as he reentered his car, some 37 minutes after the accident and 28 minutes after the substation operator was notified that the wire was down.

Who was at fault? The substation employee might have been at fault, but maybe not. Perhaps it took considerable time to rearrange circuits so as to deaden the wire in question without darkening such necessary facilities as hospitals, etc. The company's inspector was negligent in not discovering the weakened pin, if there was an inspector. If not, some superintendent was negligent in not hiring an inspector. Or perhaps the company's engineers, who designed this particular line, were wrong in putting a wire so near the road, or on a wooden rather than a metal pole. The case, then, has some similarities to the trichinosis cases where the farmer, the packer, or the housewife could have prevented the injury. The one important difference was that most of the measures which could have been taken to avoid this unfortunate accident were within the recognized jurisdiction of the power company. The substation

82. Jones v. E. Hulton \& Co., [1909] 2 K.B. 444, aff'd, [1910] A.C. 21. Liability in such cases can be justified because of its vindicatory functions alone. Clarence Morris, Inadvertent Newspaper Libel and Retraction, 32 ILI. L. REv. 36, 37-41 (1937).

83. See James, Accident Liability Reconsidered: The Impact of Liability Insurance, 57 YaLe L.J. 549, 558 (1948).

84. 117 N.J.L. 389, 189 At1. 67 (Ct. Err. \& App. 1937). 
operator, the line inspector, the engineer who designed the line, etc., were all subject to the discipline of the corporate defendant.

Insurance, of course, minimizes the impact of the judgment in cases of this kind. If the company were a self-insurer, its own funding procedures would minimize the importance of the judgment. This does not mean, however, that enterprise liability has lost all ability to induce safety practices. ${ }^{85}$ If this kind of accident became part of a pattern because many road-side poles were knocked down, or many rotted wooden pins failed, or downed lines were left charged for a considerable length of time after substation operators had been informed, some remedial action would be likely to be induced; and the cost of judgments in these situations might be valuable incentive to induce that action quickly. Even insurance may have some salutory effect upon safety practices. Insurance companies select their risks with some care. This underwriting function may have important risk minimizing effects. The insurer may call for remedial action when a pattern of accidents becomes apparent. It may employ its own engineers to study the problem and require that their recommendations be adopted before the insurance is renewed. Similarly, self-insurers, intent upon decreasing the amount they must fund, will be induced to take such action on their own. And finally, the potential economic effect of the burden of enterprise liability increases safety. As has been pointed out, this burden can not only increase price, but it can also decrease volume. It may price some hazardous practices out of a market. It will curtail the use of other hazardous activities. The added insurance expense of trucking, for instance, may induce entrepreneurs to be more careful in the management of their fleets of trucks, making sure that the trucks are only used for errands which, in the light of the expense, will be profitable, and thus decreasing the number of trucks in use.

This is not to say that risk spreading is unimportant. In any specific case not only is it important, but it is probably the most important function to be served. Most cases arise, after all, in an environment already conditioned by enterprise liability law. The safety measures that law can induce will probably have already been taken. The usual case, then, is part of the irreducible minimum of unavoidable accidents, given current knowledge and existing safety techniques. All that can be done in such a case is to spread the already realized loss. But if the case's pattern is repeated often enough, methods of reducing risk may well be devised to break the pattern. Thus, the result of the Robbins case, probably, was to discipline the substation operator. If enough similar cases occur, the company will redesign its poles, develop circuit breakers which will automatically deaden downed wires, or take some similar action.

Of course, the "reasonably prudent man" may appear out of place in this context. At least, it is not a very helpful criterion. No reasonably prudent man can distribute electricity. It is necessarily a team effort. A team's standard of performance is not easily measured by comparing it to the efforts of a hypo-

85. See James, supra note 83 , at 559-63. 
thetical individual. The negligence concept, therefore, may not be very useful. Perhaps it should be abandoned in these cases. Even if such a change has not occurred de jure, it may already have occurred de facto. ${ }^{86}$ This change, whether explicit or covert, can be described as a change to "strict liability." That does not mean, however, that it is a change to "liability without fault."

So long as enterprise liability retains its safety function, the question of fault is important. The issue becomes whether conduct within the legitimate jurisdiction of the defendant institution is of the kind which that institution should be induced to discourage. This, in turn, depends upon the general consensus of the proper role and scope of the various institutions involved. Thus, in a recent article advocating strict liability for manufacturers in products liability cases, Professor James makes a strong case for dropping negligence criteria in such cases. But he adds

[T] his does not mean that the maker would be held for all injuries caused by his products. ... [A] plaintiff must trace his injury to a quality or condition of the product which was unreasonably dangerous either for a use to which the product would ordinarily be put, or for some special use which was brought to the attention of the defendant. These are the risks and losses which may fairly be regarded as typical of the enterprise and so fairly allocable to it. Further ... plaintiff must show that this unreasonably dangerous condition existed when the goods left the maker's hands. ${ }^{87}$

Though Professor James recommends liability without negligence, he advocates liability based upon proof of unreasonable danger stemming from the condition of the product while it was still under the manufacturer's jurisdiction. He requires that the danger be a proximate cause of the injury, without intervening meddling by retailers, and that the injury be of the kind which could be anticipated. Negligence is gone, but fault has been retained under the label of unreasonable danger.

The fact that some losses can be regarded as "typical of the enterprise" does not, as Professor James intimates, lead easily to the conclusion that they are "so fairly allocable to it." 88 "Typical" as there used is not a statistical word. As already noted, the insurance experience collected for some industries is not credible. Experience covering the refining of over six million pounds of sugar annually has resulted in fewer than 27 products liability claims in a fouryear period, or less than seven per year. Such accidents; therefore, are "atypical." If, by chance, a nuclear power reactor goes out of control and blows up, no one will have to consider whether this first example of such a catastrophe

86. EHRENZWEig, NegLigence Without Fault (1951).

87. James, General Products-Should Manufacturers Be Liable Without Negligence?, 24 TenN. L. Rev. 923, 926-27 (1957). (Emphasis added.)

88. "[W] hen it comes to a fire which spreads three hundred yards from a railroad track, I have quite as much uncertainty in deciding whether it is 'typical' of a railroad enterprise as I do in dealing with it in any other way." Prosser, Palsgraf Revisited, 52 MICH. L. REv. 1, 31 (1953). 
is "typical" of the atomic power industry. It will at once be apparent that the power company should be liable. ${ }^{89}$ The word "typical," then, merely refers to the fact that the accident had important causal antecedents within the entrepreneur's proper sphere of control. In many cases this means that the accident, insofar as it was avoidable, could have been avoided by safety practices within the entrepreneur's institution. Except in those areas of the law which have no safety inducing function, such as purely inadvertent libel, the word "typical" refers to accidents which the entrepreneur has the jurisdiction to prevent and which the law seeks to have him minimize. It is, then, another reference to fault.

"Fault" as here used merely refers to conduct which we desire to discourage and which we believe can be minimized by safety techniques within the recognized jurisdiction of the institutional defendant. It means nothing more. It has no moral connotation. ${ }^{90}$ But the traditional concept of negligence probably has no important moral connotation either. The mere fact that an entrepreneur can insure against enterprise liability, though not against liability for his personally committed assaults, indicates the different moral context of the kind of fault in issue. ${ }^{91}$ The eminent authority of Holmes, speaking before the turn of the century, reminds us that law borrows ethical words but uses them in a nonmoral sense. 92

It should be remembered that a rule of law can serve more than one purpose. Clearly, the old action on the case had both the function of inducing safety and of repairing the injured. A modern negligence action, if brought against the actual tortfeasor, would have the same double function. Merely because the law raises its sights to the tortfeasor's employer, we should not assume that one of those functions is no longer served. On the contrary, the law has merely appropriated the machinery of the employer's business enterprise to achieve the same purpose it would have had in an action against the servant. We may observe that this machinery is more efficient for one of those

89. Furthermore, the power company will be insured. Kelly, Insurance Against Nuclcar Hazards, 1958 Ins. L.J. 777.

90. See Clarence Morris, Punitive Damages in Tort Cases, 44 Harv. L. Rev. 1173, 1174 n.1 (1931).

91. This point is well illustrated in an enterprise liability context by the recent case of Malanga v. Manufacturers Cas. Ins. Co., 28 N.J. 220, 146 A.2d 105 (Sup. Ct. 1958). Plaintiff was a three-man partnership in the construction business. The partnership had been held liable to a third person for an assault committed by one of the partners in the course of his partnership duties. He had intentionally run down the third party with the partnership's earth-moving machine when the third party had attempted to block the progress of the machine because it was trespassing upon his land. The defendant insurance company refused to pay the judgment. The policy included liability for assault and battery, "unless committed by or at the direction of the insured." The court held against the insurance company. "Of course," added the court, "Alfred Malanga [the tortfeasor-partner] should not individually benefit by our determination in this case. The issue of his liability to the defendant insurer under its right of subrogation is not in any way affected." Id. at 230, 146 A.2d at 110.

92. Holmes, The Path of The Law, 10 Harv. L. REv. 457 (1897). 
purposes than for the other, but a suit against the servant would not have served both purposes equally well either. Enterprise liability may change the efficiency of the law, but it does not necessarily change the ends sought.

Since enterprise liability has safety inducing functions, repairative functions, and perhaps even other functions, theories based upon only one of these are likely to fall into error. A third Smith, Bryant Smith, has made this point so well that there is no reason to state it anew. He reviews Baty's arguments and Dean Smith's answer, concluding that the entire discussion is based upon a logical fallacy.

[I]t is submitted that the practice, so widely indulged, of narrowing the basis of legal rules ... is an artificial and unsound practice. A simplicity achieved by so great a distortion of the truth comes too high. And the further application of a rule whose development is guided by such partial predication will sooner or later either deny its premises or go wrong. ${ }^{93}$

The functions of enterprise liability can be stated only in the most general of terms. It burdens the entrepreneur for a number of reasons and seeks to achieve the many different purposes for which the actionable activity is condemned. The entrepreneur may then take such remedial action as he desires, within the limits permitted by law. He may insure; he may sue over; and he may take steps to avoid the recurrence of this kind of liability. It is his move, and the law usually leaves the choice to him. The law can do this because the entrepreneur is a simple man who seeks only to maximize profits and minimize losses and who uses the resources of his enterprise to accomplish these ends. Sometimes, of course, theory departs from the facts, ${ }^{94}$ and we must legislate him back into existence, as with financial responsibility and compulsory insurance laws. But when we truly find him, we use him forr the ends of the law. The discipline of his enterprise is brought to bear upon the issue of safety. The resources of his enterprise must sustain the risk.

The entrepreneur theory, then, becomes an answer to $\mathrm{Mr}$. Baty. He was wrong. But in a sense he was right. He merely failed to recognize the dynamics of the situation. The entrepreneur's pocket is not a fixed sum, depleted by the judgment. It is an ever changing mass of assets which he administers for the greatest gain. Vicarious liability, like tax laws, rules of contract, and statutes governing labor relations, is merely one set of the rules of the game of business. It conditions the entrepreneur's efforts; it is a means of social control.

93. Bryant Smith, Cumulative Reasons and Legal Method, 27 Texas L. Rev. 454, 468 (1949).

94. See, for instance, Justice Shaw's assumption that the breadwinner, upon taking a risky job, would see the need to provide for this risk and would, therefore, demand higher wages. See text at note 70 supra. See also Professor Ehrenzweig's assumption that the guest who enters a car garaged in a guest-statute state will adjust his accident and health insurance in light of the fact that he is barred from suing his host. See text at note 21 supra. 
To be sure, it is one of the more clumsy means of social control. ${ }^{95}$ It lacks the neatness of many of its sister controls. But even those controls which have been hammered out by the legislature seem to work at cross purposes. Inheritance and income tax laws not only serve equalitarian ends by reallocating wealth, but also encourage oil wells and charitable gifts. Labor legislation not only attempts to improve collective bargaining, but also seeks to inhibit the growth of the communist party. Similarly, enterprise liability not only seeks to ease the burden of some shock losses, but also encourages safe practices and, in a society which considers business aggregates to be real, substantial beings, may even satisfy a deep felt desire for revenge against such entities. ${ }^{90}$

\section{CONCLUSION}

\section{Risk Spreading as a Rationale for Enterprise Liability}

The entrepreneur theory justifies vicarious liability, in part, by pointing out that the entrepreneur cannot claim immunity from it on the basis of a Lockean concept of property. It answers that his property is not being taken; rather, an item has been added to his costs. If his market position permits, he may spread this cost. If not, he must bear it himself, but that is one of the facts of the market, not an intent of the law.

This answer is more than a semantic trick. There is real truth in it. But it does not provide a sound premise for logical thrusts elsewhere. It is not very useful in defining the proper extent of enterprise liability. Where other factors are equal, it can point to the desirability of placing the burden upon a financially strong institution in preference to a weak one. It also stresses the importance that the burden be relatively stable from an actuarial point of view. On the other hand, a certain amount of chaos is tolerable. Most judgments of enterprise liability are chance occurrences. If the law adds additional chance elements which are of the same magnitude as those which govern losses generally, the entrepreneur can adjust to them. He can still expect that the total cost will be close to an actuarial prediction.

\section{Risk Spreading and Legal Analysis}

Prescriptive answers to zone-of-risk problems, then, must be based in the main upon other considerations. Its use in the frolic and detour problem does just this. Dean Smith would have the law judge each case in terms of what the entrepreneur would expect. As suggested above, this is tautological because the entrepreneur expects the law to judge his case as it has judged similar cases. If rules of law have been determinative, he expects them to determine his case; if the law has been doctrinally indeterminate, he expects that chaos to continue. But furthermore, Dean Smith's approach asks the im-

95. See Clarence Morris, Rough Justice and Some Utopian Ideas, 24 ILL. L. REv. 730 (1930).

96. See Mecham, Agency § 362 (4th ed. 1952). 
possible. It asks the judge or juror to occupy temporarily the entrepreneur's shoes and to adopt the entrepreneur's normative concept of the proper scope of business. The judge or juror cannot do this. He must necessarily use his own concept of what the generally accepted norm is, and he will do so even if he attempts to follow Dean Smith's advice. This approach, then, does not obscure the real problem; it merely fails to illuminate it. Cases must be judged according to generally accepted norms, and so long as these norms are used it makes little difference whom the one judging momentarily pretends to be. ${ }^{97}$

Tests which appear to rest upon economic considerations prove faulty. ${ }^{98}$ Dean Smith missed the mark when he observed that employer responsibility "for acts of his employees in no way connected with the enterprise would be undesirable because it would result in including in the cost of production an item which economically does not belong there."99 A better reason might be that such liability might induce employer attempts to improve domestic safety practices among his employees-an extension of business discipline into household matters which runs afoul of current institutional norms. But, as can be seen, the zone-of-risk analysis does not lead to false results in this area. It merely fails to articulate the reasons behind them.

97. Note the following language from 2 HaRPER \& JAMrES, TORTS 1376-78 (1956) : [We are looking] for risks that may fairly be regarded as typical of or broadly incidental to the enterprise he has undertaken. Now one of the purposes for such a quest is to mark out in a broad way the extent of tort liability (as a cost item) that it is fair and expedient to require people to expect when they engage in such an enterprise, so there can be some reasonable basis for calculating this cost. And while many things may enter into the matters of fairness and expedience . . . fairness probably cannot be altogether divorced from some kind of foreseeability. What is reasonably foreseeable in this context, however, is quite a different thing from the foreseeably unreasonable risk of harm that spells negligence. In the first place, we are no longer dealing with specific conduct but with the broad scope of a whole enterprise. . . The proper test here bears far more resemblance to that which limits liability for workmen's compensation than to the test for negligence. The employer should be held to expect risks, to the public also, which arise 'out of and in the course of his employment of labor.

Clearly, the reason foreseeability is related to fairness is that it is unfair for the law to treat an entrepreneur contrary to his reasonable expectations. He expects the law to recognize generally accepted institutional norms. Insofar as the law and his expectation reflect the same norms, he will consider the law fair. Since current institutional norms give meaning to the phrase "arising out of and in the course of" business, the law which is based upon those norms will not be unfair. Since these norms are not precise, there will be cases in which they will not be very helpful; but by that very token their decision either way will not be fair or unfair. Toward such cases the entrepreneur had doubt; he had no expectation.

98. Douglas and Clarence Morris attempt to justify the specific line between frolic and detour on the ground that the additional burden, even if calculable, would be too great. Douglas, Vicarious Liability and the Administration of Rish, 38 YALE L.J. 584, 594 (1929); MORRIs, TORTS 254 (1953). But, as Douglas admits, "the data for making exact measurements are not available." Experience with the owners' liability laws would indicate that enterprise can withstand the loss of "frolic" defenses in automobile cases.

99. See text at note 15 supra. 
In the choice-of-law field, however, the analysis does not work. Generally accepted norms do not exist, so that when the problem is considered from the entrepreneur's viewpoint, it is just as difficult as before. The fact is that conflict problems have not threatened to undermine the substantive law of torts to any great extent. In some fields, such as divorce, forum shopping is common enough to present important policy questions. Though torts is not immune from forum shopping, notably in FELA cases, most plaintiffs are shopping for liberal juries, not liberal rules of substantive law. So long as a plaintiff from Mississippi can get to a Detroit jury he is happy. He rarely cares whether the judge's charge embodies Michigan or Mississippi law. This kind of forum shopping is only important in the big case, which means it happens in only a small fraction of the cases. It has more effect upon the amount than the chance of recovery, so that if it has any effect upon insurance rates, it is likely to affect extended limits rather than basic limit rates. In other words, it is likely not to have much effect upon any particular state's rates.

The choice-of-law problem becomes, then, a technical question-one which litigants and judges must answer with some ease and certainty to permit decision in individual cases. The place-of-the-wrong rule, adopted by the Restate$m e n t,{ }^{100}$ is certainly arbitrary. Professor Ehrenzweig's basic rule that lex fori be used ${ }^{101}$ is equally arbitrary. But at least his rule would lead quickly to decisions and would avoid the difficulty of a judge's unfamiliarity with foreign, and sometimes exotic, law. Whatever rule is advocated, however, it must be argued for on the basis that this is primarily a question of technique, not of policy. It has yet to be shown that there is a danger of shopping for favorable law in a sufficient number of cases to affect the quantum of enterprise liability which entrepreneurs must sustain.

100. Restatement, Conflict of LAWs $\$ 384$ (1934).

101. Ehrenzweig, The Lex Fori-Basic Rule in the Conflict of Lawes, 58 MrcH. L. REv. 637 (1960). 


\section{THE YALE LAW JOURNAL}

VolUne 70

MARCH 1961

NUMBBER 4

RoBert E. Hudec

Editor-in-Chief

NeAle M. Albert

LAWRENCE G. GoODMAN

David M. TRUBEK

JERE A. Young

Note \& Comment

Editors
HARRISON J. GoLDIN
Article \& Book
Review Editor

SIDNEY M. WoLINSKY

Topics \& Case

Editor

Peter R. TAfT

Managing Editor

Hershel Y. AllerHand

Douglas R. AyER

Charles S. Battles, Jr.

HENRY G. BISGAIER

JOSEPE S. BORUS

Thomas B. Bracken

Carroll W. Brewster

Alan M. Dershowitz

JaN Deutsch

GeOrge B. Driesen
Benjamin S. DuVat, JR. JAMIES O. FREEDMAN JAMIES H. Gillespie David I. GoLdBLATT WilitaM S. Greenawalt

DAvid C. Greer

JoHN P. HEINZ Algernon S. Holderness, JR. ARTEUR P. JACOBS

ROBERT A. JoHNSON
LAWRENCE P. KLAMTON

ZANE KIEIN

Charles E. Lewis

JAMES L. MitchelL

Stoddard D. Platt

DAVID A. Rosen

SiDNey G. Saltz

Carol W. Trencher

AdaMe WaLinsky

HARRY J. WEXLER

Marie McMaton

Business Secretary

\section{CONTRIBUTORS TO THIS ISSUE}

Guido Calabrest. B.S. 1953, LL.B. 1958, Yale University; B.A. 1955, M.A. 1959, Oxford University. Assistant Professor of Law, Yale University.

C. RoberT Morris, JR. B.A. 1948, St. John's College (Annapolis) ; LL.B. 1951, Yale IUniversity. Professor of Law, Rutgers The State University School of Law, South Jer'sey Division. 